\title{
In CCP We Trust ... Or Do We? Assessing the Regulation of Central Clearing Counterparties in Europe ${ }^{\dagger}$
}

\author{
Hossein Nabilou* \\ Ioannis G. Asimakopoulos**
}

\begin{abstract}
As part of financial market infrastructures, central counterparties (CCPs) have long been deemed systemically important and are likely to gain in importance due to the regulatory developments mandating central clearing for an increasing number of financial products. This paper focuses on the regulation as well as the recovery and resolution of CCPs in Europe. The existing CCP regulatory framework consists of ex-ante measures, including, among others, capital and liquidity requirements, initial and variation margins, and loss sharing mechanisms. In addition, the European proposal for the recovery and resolution of CCPs (the Proposal) contains several ex-post regulatory measures mainly in the form of rules for recovery and orderly resolution.

Having studied the prudential regulatory measures for CCPs contained in the European Market Infrastructure Regulation and the ex-post recovery and resolution measures of the Proposal, this paper puts a spotlight on the specific shortcomings of the existing and proposed rules, in particular in terms of misaligned incentives, externalities, collective action problems, and certain practical impediments, and concludes that it would be misguided to inordinately rely on ex-post measures. Highlighting the limitations of the recovery and resolution mechanisms, this paper proposes that given the systemic importance of CCP functions, it is critical to improve the ex-ante measures whose objective is to prevent the failure of a CCP, rather than ex-post measures, which kick in after its failure. Accordingly, recommendations for making such improvements are proposed.
\end{abstract}

Keywords: Central counterparties, clearing, settlement, post trade, central counterparty recovery and resolution, financial market infrastructures

JEL Classification: F3, G1, G2, G3, K2, N2

\footnotetext{
$\dagger$ The authors are grateful to Dr. Randy Priem for his invaluable insights and detailed feedback on the earlier drafts of this paper. All errors are those of the authors.

${ }^{*}$ University of Luxembourg; Faculty of Law, Economics and Finance; LL.M., University of Pennsylvania Law School; Email: hossein.nabilou@uni.lu

** Doctoral Researcher and Teaching Assistant in Banking and Financial Law; University of Luxembourg; Faculty of Law, Economics and Finance; MSc (AUEB), MCL (Cantab); E-mail: ioannis.asimakopoulos@uni.lu
} 


\section{Introduction}

Financial market infrastructures (FMIs) consist of payment systems, trading venues, securities settlement systems (including central securities depositories (CSDs)), central clearing counterparties (CCPs), and trade repositories. Together, they constitute the plumbing of the financial system, which helps facilitate payments and trade in financial instruments. Within the greater FMI, CCPs play a key role in the well-functioning of the financial markets. A CCP is a legal person interposing itself between the counterparties to a trade, becoming the buyer to every seller and the seller to every buyer. ' 'Clearing' refers to the processes and activities carried out between trade and settlement. It concerns establishing positions such as calculation of net obligations, and ensuring the availability of financial instruments, cash, or both to secure the exposures arising from those positions. ${ }^{2} \mathrm{~A}$ derivatives contract is said to be cleared when the performance of the buyer and the seller is guaranteed by a CCP. Due to the different nature of derivatives contracts and their prolonged settlement date, CCPs first emerged in derivatives markets. However, they have recently made inroads into trading of broader array of securities such as stocks and bonds. ${ }^{3}$

Unlike banks and the shadow banking system, CCPs played a key role in the global financial crisis (GFC) in containing the propagation of risks and contagion of financial shocks, which otherwise could have led to a far deeper disruption during the crisis. This made CCPs the unlikely heroes of the GFC. For example, in the Lehman Bankruptcy, which put many markets across the globe in financial distress, CCPs played a key role in preventing further propagation of risks. ${ }^{4}$ By the same token, European CCPs were successful in handling the financial and sovereign debt crisis, while themselves escaping the crisis unscathed.

CCPs' success in mitigating counterparty risks in the financial markets convinced international standard setters and national regulators to pivot on these entities in the post-trade processes by requiring higher levels of CCP clearing, especially for particular classes of financial instruments such as standardized over-the-counter (OTC) derivatives. On both sides of the Atlantic, laws and regulations were passed to require the mandatory central clearing of increasing number and types of financial contracts. In the U.S., the central clearing of standardized derivatives was mandated by Title VII of the Dodd-Frank Wall Street Reform and Consumer Protection Act of 2010, and in the EU, such mandatory clearing was established by the European Market Infrastructure Regulation (EMIR). ${ }^{5}$

Although CCPs reduce risk and contribute to the efficiency of financial markets in terms of reducing capital requirements for banks, facilitating collateral management and contributing to the liquidity of

\footnotetext{
${ }^{1}$ Art. 2(1), Regulation (EU) No 648/2012 of the European Parliament and of the Council of 4 July 2012 on OTC derivatives, central counterparties and trade repositories, OJ L 201, 27.7.2012. (Hereinafter, EMIR)

2 Art. 2(3), EMIR

${ }^{3}$ CCPs first appeared in the 1970s in the U.S. stocks markets and then in Europe in 1990s, with the pioneering introduction of an equities CCP for the Paris Stock Exchange. See: Peter Norman, The Risk Controllers: Central Counterparty Clearing in Globalised Financial Markets (Chichester, West Sussex: John Wiley \& Sons, Ltd., 2011), 12.

${ }^{4}$ Ibid., Chapter 1., chapter 1.

${ }^{5}$ Regulation (EU) No 648/2012 of the European Parliament and of the Council of 4 July 2012 on OTC derivatives, central counterparties and trade repositories, OJ L 201, 27.7.2012.
} 
markets, they aggregate, concentrate and centralize risks. ${ }^{6}$ The mounting concerns about CCPs have become all the more important in the wake of the GFC, in which international fora and standard setters, such as the Group of Twenty (G20), moved towards encouraging regulatory reforms requiring central clearing of standardized OTC derivatives. Such reforms can transform CCPs into critical nodes in the financial markets the failure of which could lead to the disruption of the financial sector as well as the real economy. ${ }^{7}$ In addition to such regulatory developments in OTC derivatives markets, an increasing number of other financial products such as repurchase agreements (repos) are being cleared by CCPs. ${ }^{8}$

By default, the regulation of FMIs mainly relies on the ex-ante measures, which allow CCPs to operate safely and to absorb minor losses. In the EU, this prudential framework is provided in EMIR and applies equally to all CCPs, regardless of their legal nature. Under rare circumstances, when all prudential safeguards have failed, the treatment of CCPs differs based on their legal nature. CCPs that are banks or operate under a banking license can make use of the bank recovery and resolution directive (BRRD), whereas there is no equivalent recovery and resolution framework for non-bank CCPs at the moment. To fill this gap, as well as to provide for a harmonized recovery and resolution framework for all CCPs, the European Commission (the Commission) has issued the European proposal for the recovery and resolution of CCPs (the Proposal), ${ }^{9}$ which is currently under discussion.

This paper examines a rather under-investigated research area by shedding some light on the potential systemic fault lines in the CCP business and through discussing the respective EU risk management and resolution frameworks applicable to such entities. This paper proceeds as follows. The first section presents a brief overview of CCPs and their special role in the financial markets along with the potential systemic risks that could originate from their failure. Such an overview requires a review of the CCP business models with a view to identifying the potential market, institutional or organizational failures therein. Second, the paper examines the current ex-ante prudential regulation to assess whether the existing regulatory framework can address the potential systemic risks arising from CCPs' core activities. In doing so, the paper discusses the tools under the current regulatory regime as well as future developments based on the European proposal for the recovery and resolution of CCPs to deal with an extreme financial distress. Fourth, we elaborate on the shortcomings of the current framework, and stress the unaddressed risks. Finally, by taking stock of the limitations of the existing regulation and proposed rules, we make policy recommendations in order to strengthen the current regulatory framework.

\footnotetext{
${ }^{6}$ Umar Faruqui, Wenqian Huang, and Előd Takáts, "Clearing Risks in Otc Derivatives Markets: The Ccp-Bank Nexus," BIS Quarterly Review December 2018 (2018): 77-79.

${ }^{7}$ See Darrell Duffie and Haoxiang Zhu, "Does a Central Clearing Counterparty Reduce Counterparty Risk?," The Review of Asset Pricing Studies 1, no. 1 (2011). https://doi.org/10.1093/rapstu/rar001.

${ }^{8}$ In repo markets, traditionally, CCPs played a significantly more important role in Europe than in the U.S. Currently, about $70 \%$ of European repo market turnover is being cleared through CCPs. See: International Capital Market Association, "Frequently Asked Questions on Repo," ed. International Capital Market Association (ICMA) (2015), $25 .$.

${ }_{9}^{9}$ Proposal for a Regulation of the European Parliament and of the Council on a framework for the recovery and resolution of central counterparties and amending Regulations (EU) No 1095/2010, (EU) No 648/2012, and (EU) 2015/2365, COM/2016/0856 final - 2016/0365 (COD)
} 


\section{The CCP risk profile \\ 1.1. Are CCPs special?}

The argument for specialness of certain financial activities requiring special regulatory framework was first raised in banking. ${ }^{10}$ Offering transaction accounts, providing backup liquidity for all other financial and non-financial institutions, and the banks' role as a transmission belt for monetary policy are three features that distinguish banks from other financial and non-financial institutions. In addition to provision of payment services, the core banking functions are taking deposits and lending. Such functions often involve maturity, liquidity and credit transformation. ${ }^{11}$ Maturity transformation is beneficial because it ultimately encourages long-term capital investments, ${ }^{12}$ however, it is inherently fragile. ${ }^{13}$ Traditionally, banks had a monopoly on maturity transformation because they were the only institutions licensed to issue demand deposits. ${ }^{14}$ In addition to government safety nets, ${ }^{15}$ banks have developed specific arrangements to address risks involved in maturity transformation, which is mainly reflected in their liquidity policies. These policies often involve limiting the extent of the maturity

10 E. Gerald Corrigan, "Are Banks Special?," (Federal Reserve Bank of Minneapolis, 1982).. See also: Alan J. Marcus, "Deregulation and Bank Financial Policy," Journal of Banking \& Finance 8, no. 4 (1984). https://doi.org/10.1016/S03784266(84)80046-1.; E. Gerald Corrigan, 2000; Eugene F Fama, "What's Different About Banks?," Journal of monetary economics 15, no. 1 (1985); Eugene F Fama, "Banking in the Theory of Finance," Journal of monetary economics 6, no. 1 (1980).

However, other scholars do not agree with the 'specialness' argument for banks. For example, See Anat R. Admati and Martin Hellwig, The Bankers' New Clothes: What's Wrong with Banking and What to Do About It (Princeton, New Jersey: Princeton University Press, 2013).

${ }^{11}$ Heremans Dirk, "Regulation of Banking and Financial Markets," in Encyclopedia of Law and Economics Volume 9, ed. Roger J. Van den Bergh and Alessio M. Pacces (Cheltenham: Edward Elgar Publishing, 2011).. More often than not, the maturity transformation in banking is accompanied by liquidity transformation; however, there might be instances that banks engage in liquidity transformation without engaging in maturity transformation.

12 Financial Services Authority, The Turner Review: A Regulatory Response to the Global Banking Crisis (2009), 21.; See also Gary B. Gorton, Misunderstanding Financial Crises: Why We Don't See Them Coming (New York: Oxford University Press, 2012).

13 The fragility of maturity transformation arises from the nature of maturity mismatch between assets (long-term loans) and liabilities (demand deposits), which historically resulted in recurrent bank runs and panics. See: Tobias Adrian and Adam B. Ashcraft, "Shadow Banking Regulation," Federal Reserve Bank of New York Staff Report, no. 559 (2012): 1.; Charles P. Kindleberger and Robert Z. Aliber, Manias, Panics, and Crashes: A History of Financial Crises, vol. 5 (Hoboken, New Jersey: John Wiley \& Sons, Inc., 2005).

${ }^{14}$ Gary B. Gorton, Slapped by the Invisible Hand: The Panic of 2007 (New York: Oxford University Press, 2010).

15 In addition to banks' internal risk mitigating strategies, deposit insurance funds guarantee bank deposits up to certain limits. Deposit insurance is primarily introduced to prevent bank runs and panics, thereby to sustain financial stability. See: Alan S. Blinder and Robert F. Wescott, "Reform of Deposit Insurance: A Report to the Fdic," (2001).; Charles W Calomiris, "Is Deposit Insurance Necessary? A Historical Perspective," The Journal of Economic History 50, no. 02 (1990)..

Further, banks are provided with access to the 'discount window' or the 'lender of last resort' (LOLR) facilities of central banks.

The LOLR function of central banks is devised to prevent bank runs on illiquid but solvent banks when they have liquidity problems due to their inability to borrow from interbank market or other central bank facilities. See Xavier Freixas et al., "Lender of Last Resort: What Have We Learned since Bagehot?," Journal of Financial Services Research 18, no. 1 (2000).; Xavier Freixas and Bruno M. Parigi, "The Lender of Last Resort of the 21st Century," in The First Global Financial Crisis of the 21st Century: Part Ll June-December 2008, ed. Andrew Felton and Carmen M. Reinhart (VoxEU.org Publication, 2009), 163-67.; Carlos Garcia-de-Andoain et al., "Lending-of-Last-Resort Is as Lending-of-Last-Resort Does: Central Bank Liquidity Provision and Interbank Market Functioning in the Euro Area," ECB Working Paper Series No 1886 (2016).

Historically, the LOLR function in the market was played by private financial institutions. A bold example of taking up of such a role in the crisis of 1907 was J. P. Morgan's provision of liquidity to markets and institutions in the banking panic of that year. See Robert F. Bruner and Sean D. Carr, The Panic of 1907: Lessons Learned from the Market's Perfect Storm (Hoboken, New Jersey: John Wiley \& Sons, Inc., 2007). However, after the 1913, the year in which the Federal Reserve came into being, it took up such a function. All these protections are to ensure that banking entities' main functions, i.e., maturity transformation, and their role in payment system are not impaired because of sudden liquidity shocks. 
transformation of banks and insurance via committed credit lines from other banks, ${ }^{16}$ or borrowing from interbank repo markets.

Given the increasingly important role of CCPs in the financial markets, the same argument for specialness can be put forward for these entities. Although, as the term 'clearing bank' suggests, clearing has traditionally fallen within the realm of the banking industry, ${ }^{17}$ CCP functions and business models are thoroughly different from the core banking functions. ${ }^{18}$ A need for differential regulatory treatment can best be understood in light of CCPs' unique functions in the financial system and their potential costs and benefits for the economy at large. In this view, CCPs occupy a relatively sui generis position in financial markets and provide financial systems with 'special' benefits. For instance, CCPs mitigate systemic risk by acting as a circuit breaker when risks of defaults tend to propagate from one counterparty to another. This is made possible through either novation or open offer. Novation extinguishes the original contract between the buyer and the seller and replaces it with two new contracts: one between the buyer and the CCP, and the other between the seller and the CCP. This way, the CCP interposes itself between the original buyer and seller and becomes the buyer to the seller and the seller to the buyer. In contrast, under open offer, as the CCP immediately interposes itself between the buyer and the seller in a transaction at the very moment of its inception, no contractual relationship between the buyer and the seller is created ab initio and two separate contracts are formed: one between the buyer and the CCP and the other between the CCP and the seller. ${ }^{19}$ This way, a CCP insulates both buyers and sellers from the credit risk of the counterparties to a trade.

By standing in between counterparties, CCPs reduce the risks of panic reaction to solvency problems of a single counterparty and decrease the likelihood of sudden failure of chains of counterparties. Additionally, they enhance transparency regarding counterparty credit risk, which enables both market participants and regulators to have a better understanding and assessment of counterparty risks in the financial system, leading to greater financial stability. CCPs also monitor and ensure the uniform application of collateral requirements on all clearing members. ${ }^{20}$ Furthermore, central clearing with fewer CCPs lowers the average counterparty risk through netting. ${ }^{21}$

\footnotetext{
${ }^{16}$ Authority Financial Services, "The Turner Review: A Regulatory Response to the Global Banking Crisis," (2009), 21.

17 David Loader, Clearing, Settlement and Custody, Second ed. (Oxford: Elsevier Butterworth-Heinemann, 2014), Chapter 1.

18 Mark Jozsef Manning and David Hughes, "Central Counterparties and Banks: Vive La Difference," Journal of Financial Market Infrastructures 4, no. 3 (2016).; David Hughes and Mark Manning, "Ccps and Banks: Different Risks, Different Regulations," Reserve Bank of Australia Bulletin (December 2015).; Robert T. Cox and Robert S Steigerwald, "A Ccp Is a Ccp Is a Ccp," Federal Reserve Bank of Chicago WP2004-2 PDP, no. 2017-1 (April 2017).; Manmohan Singh and Dermot Turing, "Central Counterparty Resolution: An Unresolved Problem," IMF Working Paper WP/18/65 (2018).

${ }^{19}$ Committee on Payment and Settlement Systems and Technical Committee of the International Organization of Securities Commissions, "Recommendations for Central Counterparties: Consultative Report," (March 2004).; For more details see: Jo Braithwaite and David Murphy, "Central Counterparties (Ccps) and the Law of Default Management," Journal of Corporate Law Studies (2017). https://doi.org/10.1080/14735970.2016.1254448; Jo Braithwaite and David Murphy, "Got to Be Certain: The Legal Framework for Ccp Default Management Processes," Bank of England Financial Stability Paper No. 37 (2016).; Braithwaite and Murphy, "Central Counterparties (Ccps) and the Law of Default Management.";

20 Darrell Duffie, "Replumbing Our Financial System: Uneven Progress," International Journal of Central Banking 9, no. 1 (2013): 267.

${ }^{21}$ Duffie and Zhu, "Does a Central Clearing Counterparty Reduce Counterparty Risk?."
} 
However, the main difference between CCP business model and banking business model in that CCPs function on a matched-book basis. Namely, every position they take on the asset side of the balance sheet is offset and matched by an opposite position on the liability side of the balance sheet. Therefore, although a CCP faces various risks such as counterparty risk, liquidity risk, market risk, and operational risks, the main risk to which a CCP is exposed is the 'replacement cost risk' mainly stemming from counterparty risk. ${ }^{22}$ Therefore, given their specific features and idiosyncratic risks to which CCPs are exposed, there seems to be a consensus that there is a need for a special regulatory regime for CCPs.

\subsection{CCP systemic risk arising from core functions and operations}

Starting from the classic market failure argument, regulation is only justified when there is distortion to competition, information asymmetry or (systemic) externalities. In the case of competition, for example, there have been concerns that competition among CCPs could result in a race to the bottom and eventually lead to reduced and loosened clearing membership, ${ }^{23}$ collateral and margin requirements. To alleviate such concerns, it is suggested that fewer, but closely supervised CCPs should be the goal for regulators, as greater number of CCPs can also make supervision of CCPs difficult. ${ }^{24}$ However, this might not be the optimal policy recommendation as the main risks of a CCP to the financial system stem from the lack of substitutability. This fact favours encouraging enhanced levels of competition and lowering barriers to entry in the CCP business, even at the expense of certain forgone economies of scale and network effects.

The most important market failure in the CCP business model, though, is systemic externalities. The main sources of such externalities are counterparty risk, liquidity risk, and market risk. ${ }^{25}$ Major risks in the CCPs originate from their core activities, namely, becoming a buyer to every seller and a seller to every buyer, giving rise to counterparty risk and increasing CCPs' interconnectedness with their clearing members. This risk is further magnified in the case of derivatives contracts than in the case of equity and debt securities. The CCP, by way of novation or open offer, assumes the risk of default between the time of trade and settlement. This time is often significantly shorter in the case of securities trade (i.e., maximum $\mathrm{T}+3$ ) ${ }^{26}$ however, the settlement of a derivative instrument can be as short as that of securities or can take as long as decades. During this time span, the CCP is exposed to the risk of default of a counterparty. And since the risk is concentrated, there is concern that such a concentrated risk in the financial market would trigger a financial crisis.

\footnotetext{
${ }^{22}$ Hughes and Manning, "Ccps and Banks: Different Risks, Different Regulations."

${ }^{23}$ For a discussion of these requirements, see: Jo Braithwaite, "The Dilemma of Client Clearing in the Otc Derivatives Markets," European Business Organization Law Review 17, no. 3 (2016). https://doi.org/10.1007/s40804-016-0044-0.

${ }^{24}$ Duffie, "Replumbing Our Financial System: Uneven Progress," 254.

25 David Elliott, "Central Counterparty Loss-Allocation Rules," Bank of England Financial Stability Paper No. 2020 (April 2013): 5-6.

${ }^{26} \mathrm{~T}+3$ means the trade date plus three days settlement cycle.
} 
In addition to the losses stemming from a clearing member default, a CCP might be exposed to losses originating from other sources, such as the credit and market risk arising from the reinvestment of the cash margin and default fund contributions received from their clearing members, the risk of default by a payment or settlement bank, the risk of fraud or other operational risks. ${ }^{27}$ In principle, a CCP cannot use default waterfall to cover such losses, instead, it should rely on its own capital. Therefore, in as much as a CCP is exposed to the failure of clearing members, the failure of a CCP due to such risks can also affect other clearing members. However, the risks stemming from such risks are kept in check by private arrangements as the loss-allocation arrangements between clearing members and CCPs strive to ensure that participants could participate both in the risks and returns of such activities. $^{28}$

In addition, there are risks of interconnectedness of $\mathrm{CCP}$ activities with other banking and nonbanking activities stemming from the amalgamation of those activities in one legal entity. ${ }^{29}$ For example, in the U.S., the Federal Reserve Bank of New York (FRBNY) has been encouraging the reforms of the two major clearing banks - Bank of New York Mellon and JP Morgan Chase - because they have been operating other businesses as financial intermediaries. ${ }^{30}$ When banking activities and clearing activities comingle within a single firm, the exposures from clearing activity could affect its banking business and vice versa.

\subsection{Systemic risk arising from mandating CCP clearing}

In the EU, prior to the GFC, the OTC derivatives markets were largely unregulated. Trading OTC derivatives occurred on a bilateral basis and outside regulated organized trading venues, without any formal clearing requirements applying to them. However, the distress in the derivatives markets during the GFC engendered a reform agenda initiated by the G20. In the ensuing years, the EU financial markets witnessed two major developments that transformed the regulatory regime for derivatives and led to the transformation of the CCP business. ${ }^{31}$ The first development concerned the introduction of the requirements that mandated the derivatives to be traded on organized exchanges. The repatriation of trading of standardized derivatives from the OTC markets to organized trading venues, which was agreed upon in Pittsburgh G20 summit in September 2009, was implemented in the EU under the 2014 MiFID II/MiFIR framework. ${ }^{32}$ The underlying idea behind such a move was to

\footnotetext{
27 David Elliott, "Central Counterparty Loss-Allocation Rules," Bank of England Financial Stability Paper No. 20 (April 2013): 10 .

28 Ibid.

${ }^{29}$ BCBS et al., "Analysis of Central Clearing Interdependencies," (5 July 2017).

${ }^{30}$ Federal Reserve Bank of New York, "Tri-Party Repo Infrastructure Reform," (2018).; For the differences in the clearing of repo markets on both sides of the Atlantic, see Songjiwen Wu and Hossein Nabilou, "Repo Markets across the Atlantic: Similar but Unalike," European Business Law Review (forthcoming) (2018).

31 Though the case for mandatory trading is not as obvious as the case for mandatory CCP clearing. See Niamh Moloney, Eu Securities and Financial Markets Regulation, 3 ed. (Oxford: Oxford University Press, 2014), 623.

32 The clearing/margin and reporting requirements imposed by EMIR and trading requirement imposed by MIFID II and MiFiR.
} 
increase the resilience and transparency of derivatives trading, and regulatory monitoring, operational and liquidity risk management. ${ }^{33}$

Second was the introduction of the requirement for CCP clearing. Effective June 2016, in Europe, EMIR required central clearing of certain standardized OTC derivatives. ${ }^{34}$ Encouraging central clearing is not limited to directly mandating central clearing of financial contracts, but it also includes certain indirect incentives for central clearing. For example, under Basel II framework, zero riskweights were assigned for the counterparty credit risks to derivatives or securities financing transactions (SFTs) and to banks' credit risk exposure resulting from such transactions outstanding with a CCP, ${ }^{35}$ though supervisors could still require capital to fund such exposures. Although more recently such a regulatory subsidy has been replaced by a risk-weighting of 1-3\% for banks' collateral exposure to $\mathrm{CCPs},{ }^{36}$ the overall higher capital requirements for non-centrally cleared derivative contracts, introduced as part of the CRD IV package, plays a significant role in encouraging central clearing. ${ }^{37}$

Nevertheless, such regulatory developments can backfire. As mentioned earlier, there is a clear consensus in the financial markets that CCPs do not eliminate risk. They just reallocate and most likely centralize it, which gives rise to new vulnerabilities in the financial market as central clearing tends to concentrate risks in a few major $\mathrm{CCPs} .{ }^{38}$ In that regard, a new risk management framework was introduced. In the next two sections, we sketch and critically assess this framework from a prudential (part 2) and recovery and resolution perspective (part 3).

\section{Prudential regulation of CCPs in Europe}

Since the smooth functioning of an infrastructure, such as a CCP, is fundamental to financial stability, the importance of prudential regulation is even more crucial than in the case of banks. Prudential regulation of CCPs consists of various micro and macroprudential regulation as well as structural regulation, which in many cases share the same attributes of the requirements applicable to banking and other financial institutions. ${ }^{39}$

\footnotetext{
${ }_{33}$ See: Moloney, Eu Securities and Financial Markets Regulation, Chapter VI, Section 4.3. \& p. 433.; Financial Stability Board, "Implementing Otc Derivatives Market Reforms," (2010), 39-43..

${ }^{34}$ On the other side of the Atlantic, title VII of the U.S. Dodd-Frank Act introduced similar requirements.

35 Bank for International Settlements (June 2006), 'International convergence of capital measurement and capital standards: A revised framework', Comprehensive Version, Basel Committee on Banking Supervision.

See: Basel Committee on Banking Supervision, "Capital Requirements for Bank Exposures to Central Counterparties," (Basel: Bank for International Settlements, April 2014).

${ }^{36}$ Bank for International Settlements (26 July 2010), 'The Group of Governors and Heads of Supervision reach broad agreement on Basel Committee capital and liquidity reform package', Basel Committee on Banking Supervision, press release plus Annex. See Section 21.3. See also: Norman, The Risk Controllers: Central Counterparty Clearing in Globalised Financial Markets, 15.

${ }^{37}$ See Art. 429 Capital Requirements Regulation (CRR)

${ }^{38}$ Faruqui, Huang, and Takáts, "Clearing Risks in Otc Derivatives Markets: The Ccp-Bank Nexus."

${ }^{39}$ For an overview of such regulatory objectives and toolkits applicable to banking entities, see Stuart I. Greenbaum, Anjan

V. Thakor, and Arnoud W. A. Boot, "Objectives of Bank Regulation," in Contemporary Financial Intermediation, ed. Stuart

I. Greenbaum, Anjan V. Thakor, and Arnoud W. A. Boot (San Diego: Academic Press, 2016).; Richard J. Herring and
} 
In Europe, EMIR imposes prudential requirements on CCPs. The existing EMIR framework heavily relies on ex-ante measures, which are those that make it unlikely for a CCP to fail. These measures consist of a plethora of micro and macroprudential measures, such as capital requirements, margin and haircut standards, loss-sharing arrangements, prudential rules on the CCP's investment policies, liquidity requirements, and clearing membership standards.

However, before overviewing CCP regulation in Europe, it is important to mention that to fend off the counterparty risks to which a CCP is exposed due to its core operation (clearing), the CCP often has its own risk management toolkit included in its rulebook. As part of its risk management toolkit, a CCP collects initial and variation margin from clearing members to manage counterparty risks ${ }^{40}$ If the initial and variation margin is not adequate to cover the losses, the use of a default waterfall is triggered. A pre-funded default fund (also known as 'guarantee fund') is the one that mutualizes the residual loss among surviving clearing members. The CCP itself may contribute to this fund from its own capital. Moreover, the rights of assessment is an additional predetermined amount that is contributed by non-defaulting clearing members after the prefunded default funds have been completely depleted. At the latest stage comes the CCP's remaining equity. If losses are larger than this equity, CCP becomes insolvent. ${ }^{41}$ In addition to the above, CCPs often have a recovery toolkit, and specific loss allocation rules within their rulebook the aim of which is to ensure that the CCP returns to a matched book.

With respect to the legally mandated prudential safeguards, as a condition for authorization, EMIR requires a CCP to have a permanent and available initial capital of at least EUR 7.5 million. ${ }^{42}$ The amount of own resources that the CCP must dedicate is known as the 'skin in the game', which arguably aligns the interest of clearing members with those of the CCP's shareholders or management. The minimum level of the CCP's skin in the game is set at $25 \%$ of its capital requirements, which shall be revised on an annual basis. ${ }^{43}$ Since CCPs operate on a matched-book basis ${ }^{44}$ imposing higher levels of capital requirements - although can increase skin in the game - may not be very helpful as a microprudential tool. ${ }^{45}$

In addition, a CCP should impose margin requirements both on its clearing members and other CCPs with whom it has established interoperability arrangements. This margin should be sufficient to cover potential exposures, in particular, potential losses originating from "at least $99 \%$ of the exposures

Anthony M. Santomero, "What Is Optimal Financial Regulation?," in The New Financial Architecture: Banking Regulation in the Twenty-First Century., ed. Benton E. Gup (Westport, Connecticut: Quorum Books, 2000).

${ }^{40}$ In case a clearing member defaults on paying the variation margin, the CCP might be exposed to market risks as it needs to enter into an offsetting or hedging transaction or auction off the defaulting members positions to the non-defaulting clearing members. In the meantime, the prices of the assets could move against the $\mathrm{CCP}$, which could expose it to market risk; initial margin is a protection against this market risk.

${ }^{41}$ Elliott, "Central Counterparty Loss-Allocation Rules," 5-6.

${ }^{42}$ Art. 16 EMIR

${ }^{43}$ Art. 35 (2). Commission Delegated Regulation (EU) No 153/2013 of 19 December 2012 supplementing Regulation (EU) No 648/2012 of the European Parliament and of the Council with regard to regulatory technical standards on requirements for central counterparties, $O J L$ 52, 23.2.2013.

44 Meaning that any change in the value of CCPs claims against one clearing member is exactly matched by an opposite change in the opposite direction in the value of its claim against another clearing member.

45 Instead, it seems that the most relevant microprudential requirement for CCPs would be liquidity requirements. 
movements over an appropriate time horizon". ${ }^{46}$ Although CCPs are allowed to practice portfolio margining, ${ }^{47}$ they are prohibited from using the margins posted by non-defaulting clearing members to cover the losses stemming from the default of another clearing member. ${ }^{48}$

Ex-ante regulation of CCPs can also include macroprudential requirements such as countercyclical margin requirements. Mitigating procyclicality of margin requirements in derivatives transactions has been a major policy objective in regulating CCPs. The EU approach aims to contribute to financial stability through making it unnecessary for the CCPs to exert liquidity pressures on clearing members in times of distress. EMIR's main objective from setting margin requirements is microprudential, i.e., safeguarding individual CCPs, however, cognizant of the potential procyclicality of margin requirements, it requires CCPs to take the procyclical consequences of margin requirements into account in setting and enforcing their margining policy. Moreover, there is considerable support, in particular, by the European Central Bank (ECB), to include the macroprudential intervention tools in EMIR by granting authorities the power of setting time-varying margins and haircut requirements on derivative transactions to limit the procyclicality of margins and haircuts. ${ }^{49}$

A CCP is also required to fully collateralize its exposures to all its clearing members or other CCPs on a daily basis. ${ }^{50}$ EMIR only sets qualitative standards for collateral to be accepted by the CCP, but ultimately, it is the CCP that decides what to accept and what not to accept as collateral. ${ }^{51}$ To cover its exposures to its clearing members, a CCP should only accept highly liquid collateral with minimal credit and market risks. Adequate haircuts should also be applied to collateral proportional to its risk profile. ${ }^{52}$ To mitigate potential counterparty risk stemming from the medium of settlement, to the extent possible, a CCP should use central bank money (CeBM) for settling its transactions. If a CCP does not use CeBM, it should take appropriate measures to limit its cash settlement risks. ${ }^{53}$

EMIR further requires CCPs to assess their liquidity and credit exposures on a near to real-time basis. ${ }^{54}$ In addition, it imposes several other prudential requirements on the CCP's investment policy regarding its financial resources. The financial resources of a CCP should be invested in cash or highly liquid financial instruments with minimal market and credit risk. ${ }^{55}$ If not, the amount of capital (including retained earnings and reserves) cannot be taken into account for the purposes of dedicated own resources to be used according to the default waterfall. Such funds cannot also be calculated for

\footnotetext{
46 Art. 45 (4) EMIR

${ }^{47}$ Art. 41(4) EMIR

48 Art. 45 (4) EMIR. More recently, EU regulatory technical standards (RTS) have been published on margin requirements for CCPs, based on article 11 of EMIR. See Commission Delegated Regulation (EU) 2016/2251 of 4 October 2016 supplementing Regulation (EU) No 648/2012 of the European Parliament and of the Council on OTC derivatives, central counterparties and trade repositories with regard to regulatory technical standards for risk-mitigation techniques for OTC derivative contracts not cleared by a central counterparty, C/2016/6329; OJ L 340, 15.12.2016.

${ }_{49}$ European Central Bank, Financial Stability Review (May 2016), 106-08.

${ }^{50}$ Art. 41(1) EMIR

51 Art. 46 EMIR

52 Art. 46(1) EMIR

53 Art. 50(1) EMIR

54 Art. 40 EMIR

55 Art. 47(1) EMIR
} 
the purposes of meeting CCP's capital requirements. ${ }^{56}$ Furthermore, margins or default fund contributions should be deposited with operators of securities settlements systems, ensuring full protection of those financial instruments. ${ }^{57}$ Asset separation rules apply where a CCP deposits assets with a third party. ${ }^{58}$ In its investment decisions, a CCP should also set acceptable concentration limits to its overall risk exposure to a single obligor. ${ }^{59}$

In addition to EMIR's liquidity requirements on $\mathrm{CCPs},{ }^{60} \mathrm{EMIR}$ requires that $\mathrm{CCPs}$ should have access to credit lines or similar arrangements to meet their liquidity needs if their available financial resources are not immediately available. ${ }^{61}$ Only up to $25 \%$ of the credit line can be provided by a single clearing member, parent undertaking or subsidiary of the clearing member. ${ }^{62}$

To cover the losses originating from the default of clearing members, in excess of the ones covered by margin requirements, a CCP is required to maintain a prefunded default fund. This fund helps limit the CCP's credit exposure to its clearing members. ${ }^{63}$ Again, EMIR does not set minimum requirements, however, it requires the CCP to set a minimum amount for such funds. ${ }^{64}$ The default fund is composed of contributions of clearing members, which should be risk-based and proportional to the exposures of each clearing members. ${ }^{65}$ The default fund should enable the CCP to withstand the default of the clearing members to which the CCP has the largest exposures or in case that the sum of the second and third largest members is larger than the clearing member with the largest exposure, the default fund should enable the CCP to withstand their defaults. ${ }^{66}$ The CCP is allowed to establish several default funds for each class of financial instruments that it clears. ${ }^{67}$ Article 45 EMIR stipulates that in a default situation, the contributions of non-defaulting party can only be used if both the contributions of defaulting member and the dedicated own resources of the CCP has been exhausted.

Additional sufficient prefunded available financial resources should be maintained by the CCP for covering potential losses exceeding the losses covered by margin requirements. These other financial resources consist of the CCP's freely available dedicated resources and cannot be used for capital requirement purposes. ${ }^{68}$ The default fund and other financial resources should enable the CCP to withstand the default of at least the two clearing members with the largest exposures to CCP under

\footnotetext{
56 Art. 47(2) EMIR

57 Art. 47(3) EMIR

58 Art. 47(5) EMIR

${ }^{59}$ Art. 47(7) EMIR

${ }^{60}$ Art. 44 EMIR

${ }^{61}$ Art. 44(1) EMIR

62 Art. 44(1) EMIR

${ }^{63}$ Art. 42(1) EMIR

${ }^{64}$ Art. 42(1) EMIR

${ }^{65}$ Art. 42(2) EMIR

${ }^{66}$ Art. 42(3) EMIR

${ }^{67}$ Art. 42(4) EMIR

68 Art. 43(1) EMIR
} 
extreme but plausible market conditions. ${ }^{69} \mathrm{CCPs}$ can also require the non-defaulting clearing members to provide additional funds in the event of default of another clearing member. ${ }^{70}$

This loss-sharing arrangement could potentially result in socialization of losses and eventually lead to adverse selection problems, in the sense that weak clearing members would always remain in the market and stronger ones would exit. Such a mechanism bears striking resemblance to ex-post funding of deposit insurance, which punishes the surviving good banks. In addition, similar to deposit insurance in banking, where ex-post contributions can be procyclical, ex-post loss-sharing arrangements in CCPs would not be immune to procyclicality.

Among other safety enhancing measures is formalizing access to central bank liquidity facilities or certain insurance arrangements with a public backstop. This is more relevant in the case of provision of clearing services by non-bank CCPs, or CCPs not affiliated with banks. In principle, a CCP may find itself in need of additional or outside sources of liquidity in two instances. First is the intraday funding needs for ensuring the discharge of the daily payment obligations (e.g., variation margins). This liquidity need can be met by commercial banks and can only address operational risks. The second instance of liquidity needs would be under stressed circumstances or in times of systemic events leading to liquidity problems in CCPs, wherein a liquidity backstop from a central bank would be needed.

In addition to the above prudential regulation framework applicable to the European CCPs, given their increasingly important role they play as part of the FMIs, a proposal for a new framework for orderly recovery and resolution of a CCPs is put forward at the EU level. The next section explores this framework with a view to identifying the potential shortcomings of this proposal.

\section{Final line of defence: Recovery and resolution}

\subsection{Current framework}

As CCPs conduct functions that are systemic, the objective of the prudential regulation of CCPs should be to make the need for recovery and resolution tools redundant. ${ }^{71}$ A failed CCP would imply that all the internal risk management policies and procedures as well as the EMIR safeguards have failed to contain the crisis. At the moment, a default by a clearing member holding a bank license means that bank resolution tools have also failed to deliver. That is in itself quite unlikely since bank resolution allows for banks to be resolved without bailing in certain liabilities that could generate

\footnotetext{
${ }^{69}$ Art. 43(2) EMIR

${ }^{70}$ Art. 43(3) EMIR

71 This is evidenced by the fact that CCP failures have been extremely rare, however, once they have failed, they have often resulted in market shutdown. For case studies of CCP failures, see Vincent Bignon and Guillaume Vuillemey, "The Failure of a Clearinghouse: Empirical Evidence," Banque de France Working Paper No. 638 (2017).; Bob Hills et al., "Central Counterparty Clearing Houses and Financial Stability," Financial Stability Review, Bank of England 6, no. 2 (1999).; Robert T. Cox, David Murphy, and Edward Budding, "Central Counterparties in Crisis: International Commodities Clearing House, New Zealand Futures and Options Exchange and the Stephen Francis Affair," Journal of Financial Market Infrastructures 4 , no. 3 (2016). https://doi.org/10.21314/JFMI.2016.054.
} 
contagion risks; such liabilities could be the banks' obligations to CCPs. ${ }^{72}$ However, despite all the existing safeguards, a failure of a major CCP is not entirely unlikely, especially if such a failure originates from the failure of multiple clearing members. The recent studies on CCP interdependencies leave raised concerns about such an eventuality. For example, exposures to CCPs are concentrated among a small number of institutions, and the contribution by the largest 20 out of 307 clearing members (included in this analysis) account for approximately $75 \%$ of total financial resources (initial margin and default fund) that those members provide to CCPs. ${ }^{73}$ This study also indicates that the default of a CCP's top two clearing members could result in defaults of the same entity or affiliates in up to 23 other CCPs included in the analysis. ${ }^{74}$ Although the current EU bank recovery and resolution regime is applicable to CCPs holding a banking license, it leaves the nonbank CCPs out of its scope, which could prove to be a potential source of risk for CCPs.

The CCP recovery and resolution regimes differ across jurisdictions. ${ }^{75}$ In the UK, the legislative framework has been amended to provide $\mathrm{CCP}$ recovery and resolution tools to the $\mathrm{CCP}$ supervisor, i.e., the Bank of England in its functionally separate resolution authority. ${ }^{76}$ The objectives of the recovery and resolution framework include ensuring the continuity of CCP core services, avoiding the use of public funds, avoiding interference with property rights, protecting financial stability, and enhancing public confidence in the financial system. However, given the fact that there is no hierarchical order among those objectives, it is clear that this framework diverges from the spirit of the bank recovery and resolution framework, which prioritizes the use of private funds within a resolution. In this framework, recovery plans are linked to the establishment of loss allocation mechanisms to be activated once the default resources envisaged under EMIR are depleted. Resolution plans are mainly linked to the power to sell part or all of the CCP business and to establish a bridge institution. Compensation to the affected parties can be provided. Unilateral (noncontractual) loss absorption mechanisms are, however, missing.

Current recovery and resolution frameworks in different member states are significantly varied. For example, in Italy, the resolution framework for FMIs was extended to CCPs. ${ }^{77}$ It now includes a Special Administration Regime (SAR), aimed at preserving the CCP's business continuity, and a Compulsory Administrative Liquidation Regime (CALR). A CCP may be subject to the SAR if serious irregularities in the management of the CCP and/or serious capital shortfalls arise. On the other hand, it might be placed under the CALR if authorisation has been withdrawn by the competent

\footnotetext{
72 Art. 44(3) BRRD

73 BCBS et al., "Analysis of Central Clearing Interdependencies."; See also BCBS et al., "Analysis of Central Clearing Interdependencies," (9 August 2018).

${ }^{74}$ BCBS et al., "Analysis of Central Clearing Interdependencies."

${ }^{75}$ European Commission, "Impact Assessment Proposal for a Regulation of the European Parliament and of the Council on a Framework for the Recovery and Resolution of Central Counterparties and Amending Regulations (Eu) No 1095/2010, (Eu) No 648/2012, and (Eu) 2015/2365 \{Swd(2016) 369 Final\}," (28.11.2016).

76 The Financial Services and Markets Act 2000 (Over the Counter Derivatives, Central Counterparties and Trade Repositories) (No. 2) Regulations 2013

77 Commission, "Impact Assessment Proposal for a Regulation of the European Parliament and of the Council on a Framework for the Recovery and Resolution of Central Counterparties and Amending Regulations (Eu) No 1095/2010, (Eu) No 648/2012, and (Eu) 2015/2365 \{Swd(2016) 369 Final $\}, " 12$.
} 
supervisory authority - the Bank of Italy - or the courts have declared the CCP to be insolvent. As part of this regime, the operations of the CCP would be frozen, all CCP payments would be suspended, and contracts would be terminated. In France and Germany, CCPs are required to have a banking license. ${ }^{78}$ Consequently, their authorities have the powers envisaged under the BRRD. However, in that case not all tools can be effectively applied to CCPs.

Overall, the current framework is fragmented and there is significant uncertainty as to the treatment of a failed CCP in each of those jurisdictions. However, in countries where large CCPs are established, different variations of recovery and resolution measures are already in place. It appears, however, that the role of bail-in is currently non-existent, and priority is given to the use of the sale of business tool combined with the provision of public funding. Indeed, on the one hand, assuming that the failure of the CCP has not resulted from an external shock (e.g., hacking) but is the outcome of a systemic crisis, bailing-in the clearing members could prove to be detrimental to financial stability. On the other hand, though, in case of a large CCP, trying to apply resolution without bail-in could prove catastrophic for its home country. In addition, a main challenge is that, given the lack of proper recovery and resolution planning, trying to understand and preserve the different critical functions of a CCP within strict time limits will be challenging, to say the least.

\subsection{Future developments}

In the future, the European proposal for the recovery and resolution of CCPs (the Proposal) is to put in place a harmonized framework for CCP recovery and resolution. In this section we examine this proposal by drawing comparisons to its banking equivalent and drafting model, the BRRD, as well as the BRRD's version for Banking Union countries, the Single Resolution Mechanism Regulation (SRMR). ${ }^{79}$

In the EU, the rules governing bank recovery and resolution are integrated within the BRRD and the SRMR. The SRMR establishes the resolution framework applied to all Eurozone Member States and sets out the rules regarding the functions and operations of the European resolution authority, the Single Resolution Board (SRB), whereas the BRRD sets a harmonized resolution framework for all non-Eurozone countries. Whilst the substantive components of the two texts are identical, the difference lies in the procedural framework related to the enforcement of the rule, as the BRRD - in contrast to the SRMR - contains a purely national, non-centralised enforcement system. That said, as the analysis of the Proposal unfolds, the comparison with the BRRD and SRMR is used to identify similarities, divergences, and weaknesses therein.

\footnotetext{
${ }^{78}$ Ibid.

${ }^{79}$ Regulation (EU) No 806/2014 of the European Parliament and of the Council of 15 July 2014 establishing uniform rules and a uniform procedure for the resolution of credit institutions and certain investment firms in the framework of a Single Resolution Mechanism and a Single Resolution Fund and amending Regulation (EU) No 1093/2010, OJ L 225, 30.7.2014, p. 1-90. (Hereinafter SRMR).
} 
Faithful to the BRRD model, the Proposal sets rules related to the treatment of a CCP at an early stage, when it is under financial distress but remains solvent (recovery phase), and rules that relate to the later stage when CCP failure cannot be prevented, and liquidation should be avoided on financial stability grounds (resolution phase).

Within the CCP recovery framework, CCPs are required to draw up and maintain a recovery plan to be implemented in case of financial distress, ${ }^{80}$ following the triggering of certain indicators that are chosen by the CCP and agreed by the regulator. ${ }^{81}$ The plans need to be submitted to and approved by the competent resolution authorities. ${ }^{82}$ Moreover, those plans undergo a resolvability assessment aiming at identifying potential material impediments to an effective recovery (and resolution). In this context, structural, financial or organizational measures might be ordered by the resolution authorities to improve the CCP's resolvability. The plan is also provided to the EMIR college of the CCP to allow its members to analyse the consequences of the potential implementation of the plan to clearing members, their clients and the financial markets served by the CCP. ${ }^{83}$

As required by the Commission, recovery measures should take the form of a contractual arrangement between the CCPs and their clearing members in accordance with the pre-agreed operating rules. Such contractual arrangements might include: tearing up contracts - terminating contracts so that losses and gains can be crystallized - in order to re-match the CCP's book; establishing voluntary agreements such as auctions with the remaining clearing members so that they can voluntarily take on positions or to arrange 'cash calls' - that is requiring clearing members to provide additional resources; and 'variation margin haircutting' - that is haircutting payments due to the clearing members as a result of profits gained in a derivatives contract. ${ }^{84}$ As examined below, the said measures can also be used as resolution measures with the difference that the former are integrated within the operating rules of the $\mathrm{CCP}$, and thus clearing members have an upfront indication on the measures that can have direct implications for their own financial situation, and can therefore better calibrate their own risk management strategy. ${ }^{85}$ Beyond those included in the recovery plan, recovery measures can go as far as contacting potential buyers as resolution is approaching, requiring structural and/or operational changes to the CCP, or removing the senior management and the board of the CCP. ${ }^{86}$

In terms of resolution, and given the precedent of BRRD and EMIR, CCP resolution authorities are required to establish and chair resolution colleges for each CCP. These colleges shall consist primarily of the EMIR college participants ${ }^{87}$ plus all the different competent resolution authorities. ${ }^{88}$

\footnotetext{
${ }^{80}$ Art. 9(1) of the Proposal.

${ }^{81}$ Art. 9(2) of the Proposal.

${ }^{82}$ Art. 9(4) of the Proposal \& Art. 10(1) of the Proposal.

${ }^{83}$ Randy Priem, "Ccp Recovery and Resolution: Preventing a Financial Catastrophe," (2017): $13 .$.

${ }^{84}$ Ibid.

${ }^{85}$ Ibid.

86 Art. 20 of the Proposal.

${ }^{87}$ Namely, ESMA, the CCP's competent authority, the competent authorities that supervise the clearing members of the CCP that are established in the three member states with the largest contributions to the default fund of the CCP, the
} 
Content-wise, resolution authorities draft resolution plans according to the guidelines set out in the Proposal, ${ }^{89}$ which again mirrors the BRRD adjusted to the specificities of a CCP's operations. Assessment of resolvability is part of resolution planning as is for recovery planning; ${ }^{90}$ hence, structural, organizational, and financial measures can be imposed here as well. ${ }^{91}$ Resolution colleges need to agree upon the resolution plans. If no agreement is achieved within the colleges, the (national) resolution authority itself will be the one to decide upon those measures. ${ }^{92}$ However, especially regarding the resolvability measures that relate to the structural and operational aspects of the CCP, any member of the resolution college can refer to ESMA, whose decision through mediation will then be binding upon the national resolution authority. ${ }^{93}$

In the execution phase of resolution, the conditions for resolution are identical as in the BRRD, namely that the CCP is failing or likely to fail (FOLTF), that no private sector alternatives to resolution are available, and that the resolution is justified on public interest grounds to achieve the resolution objectives that normal insolvency proceedings would fail to do. ${ }^{94}$ The triggering mechanism, according to the Proposal, remains strictly in the hands of the national resolution authority, who is competent to make the said assessments. However, compared to bank resolution, here the EMIR college will likely signal to the national authority that a FOLTF assessment has to be made since the college receives sufficient data on a monthly basis to make such an assessment.

Nonetheless, there are certain principles that need to be followed in resolution. ${ }^{95}$ All contractual obligations and arrangements need to be exhausted first before the entry into resolution, unless the resolution authority decides that their partial use is preferable in order to preserve the CCP's critical functions, financial stability and the rest of the resolution objectives. ${ }^{96}$ The rest are identical to the principles applied in bank resolution, namely shareholders bear losses before creditors, pari passu principle is to be applied, as well as the No Creditor Worse Off principle (NCWO) ${ }^{97}$

With respect to the resolution tools available to the resolution authorities, there is greater flexibility provided in the proposal than in BRRD. In particular, there are four specific measures included in the

competent authorities responsible for the supervision of trading venues served by the CCP, the competent authorities supervising CCPs with which interoperability arrangements have been established, the competent authorities supervising CSDs that are linked to the CCP, the relevant members of the ESCB, and the central banks of issue of the most relevant union currencies. Article 4 of the Proposal.

${ }^{88}$ The resolution authority of the CCP, the resolution authorities of the clearing members of the CCP that are established in the three member states with the largest contributions to the default fund of the CCP, the resolution authorities of the CCPs with which interoperability arrangements have been established, the competent authority of the parent undertaking, if applicable, the competent ministry and the European Banking Authority (EBA). Art. 4 of the Proposal.

89 Art. 13 of the Proposal.

${ }^{90}$ Art. 16 of the Proposal.

91 Art. 17(7) of the Proposal.

92 Art. 18(3) of the Proposal.

93 Art. 18(4) of the Proposal.

${ }^{94}$ Art. 12(1) of the Proposal.

${ }^{95}$ Art. 23 of the Proposal.

${ }^{96}$ Banking practice has shown that emphasis is given to these two objectives, see Silvia Merler, "Critical Functions and Public Interest in Banking Services: Need for Clarification? Banking Union Scrutiny. Bruegel Report, November 2017," (2017).; Willem Pieter de Groen, "The Provision of Critical Functions at Global, National or Regional Level. Is There a Need for Further Legal/Regulatory Clarification If Liquidation Is the Default Option for Failing Banks? Ceps Special Report, 19 December 2017," (2017).

${ }^{97}$ Art. 23(e) of the Proposal. 
Proposal; position and loss allocation tools, ${ }^{98}$ write-down and conversion tools, sale of business tool, and the bridge CCP tool. ${ }^{99}$ Apart from that, resolution authorities have the power to implement any other resolution tool consistent with the resolution objectives and the general resolution principles.

The position allocation tool (PAT) ${ }^{100}$ aims to rematch the books of the CCP or the bridge CCP where relevant. The execution of the PAT takes place through the partial or full termination of contracts, which falls within the competence of the resolution authority. The full termination of contracts is, however, unlikely as it could generate systemic risks due to the simultaneous loss allocation across the members of the CCP, which would leave them unhedged at the most critical point trying to rebalance their books at the time of financial distress. ${ }^{101}$ The systemic concerns arise from considerations that are similar to those in bank resolution, where senior creditors are not bailed-in despite clear rules providing that they should be part of the bail-in process.

Regarding the loss allocation tool (LAT), the proposal refers to the variation margin gains haircutting $(\mathrm{VMGH})^{102}$ and the resolution cash calls. ${ }^{103}$ The former allows the resolution authority to reduce or cancel due variation margin payments to non-defaulting clearing members, while it would continue to accept variation margin payments from the members as usual; this has been characterized as a very effective resolution tool, ${ }^{104}$ even though it tends to create procyclical effects and is not suitable for non-default losses, or for instruments such as repo transactions where margins are not being used. ${ }^{105}$ Initial margin haircutting is not included (but neither excluded) in the Proposal - aligned with the provisions of EMIR - because, similar to risk-based capital requirements or initial margin requirements, it would lead to pro-cyclical effects due the lack of collateral and the need to trigger immediate margin calls. ${ }^{106}$ Moreover, initial margin haircutting would be self-defeating, because it

\footnotetext{
98 The position and loss allocation tool can also be part of the recovery plan. However, it needs to be performed contractually, namely, it has to be integrated in advance in the CCP's operational rules and cannot be imposed unilaterally by the resolution authority as is the case in resolution. See Priem, "Ccp Recovery and Resolution: Preventing a Financial Catastrophe," $12 .$.

${ }^{99}$ Art. 27 of the Proposal.

100 Art. 29 of the Proposal.

101 Thomas Huertas, "How to Deal with the Resolution of Financial Market Infrastructures," (2016).. CPMI and IOSCO also argue against a full termination of contracts, see Committee on Payments and Market Infrastructures and Technical Committee of the International Organization of Securities Board of the International Organization of Securities Commissions, "Recovery of Financial Market Infrastructure," (Basel, Switzerland: Bank for International Settlements and International Organization of Securities Commissions, 2017).

102 Art. 30 of the Proposal.

103 Art. 31 of the Proposal.

104 Rama Cont, "The End of the Waterfall: Default Resources of Central Counterparties," Journal of Risk Management in Financial Institutions 8, no. 4 (2015).

105 Priem, "Ccp Recovery and Resolution: Preventing a Financial Catastrophe," 13.

106 Where a deterioration in the positions of a clearing member would trigger additional margin calls, providing extra margins by that clearing member would further deteriorate its position and lead to amplifying effects of the shocks to that clearing member. Haircuts on initial margins would effectively work in the same manner and would aggravate the financial difficulties in times of distress. See also International Swaps and Derivatives Association, CCP Loss Allocation at the End of the Waterfall, 2013 available at: available at: https://www2.isda.org/...==/CCP_loss_allocation_waterfall_0807; Nasdaq Clearing. (2014), Recovery and resolution for ${ }^{-}$CCPs, available at: http://business.nasdaq.com/Docs/Recovery\%20and\%20Resolution\%20for\%20CCPs.pdf;

LCH.Clearnet. (2014), Recovery and resolution: a framework for CCPs, available at: http://www.lch.com/documents/731485/762444/-and-resolution-a-framework-for-ccps.pdf/.
} 
threatens to affect the critical function of the $\mathrm{CCP}$ as soon as its capacity to ensure counterparty performance deteriorates. ${ }^{107}$

With respect to the sale of business too ${ }^{108}$ and the bridge CCP tool, ${ }^{109}$ the resolution authority may transfer to a purchaser or to a bridge CCP owned by the resolution authority all instruments of ownership issued by a CCP under resolution and any assets, rights, obligations or liabilities of the CCP in question. The transfer takes place without the consent of the shareholders of the CCP and compared to BRRD - without the purchaser having the authorization to provide clearing services, as long as the new entity has the operational capacity to perform the CCP's critical functions and adjusts its risk management policy accordingly. ${ }^{110}$

Moreover, inherent in the utility of the sale of business tool or the bridge bank tool is the power to break an institution into a good and a bad institution. In bank resolution framework, a bank can be broken into a good and a bad bank, with the aim of avoiding a disruption in the critical functions. This framework also allows for granting priority to certain creditors. However, a potential failure in a typical bank is likely to result in the failure of its entire business model. In the case of CCPs the situation is similar. Some CCPs' business models and balance sheet structures are complex enough to include not only clearing functions, but also other activities such as portfolio compression techniques and tri-party repo management. In these cases, certain functions could indeed be saved, and the rest could be left in a 'bad' CCP.

Government financial stabilization tools are the last-resort mechanism to rescue the CCP in resolution. However, compared to BRRD, here the framework seems more flexible. Under BRRD, any recourse to public financing needs to take place only after the full $8 \%$ of the bank's liabilities have been bailed-in. In the case of CCPs, the only limits to the use of public funds is the limited burden-sharing under the State aid rules, ${ }^{111}$ and the requirement that the other resolution tools have been assessed and exploited to the maximum extent practicable whilst maintaining financial stability. ${ }^{112}$

\section{Regulatory shortcomings and potential future risks}

The aforementioned lines of defence, including the prudential rules and proposed recovery and resolution plans suffer from certain shortcomings to which we return in this section. These shortcomings involve externalities that need to be internalized, collective action problems in the proposed resolution of CCPs as well as broader enforcement weaknesses inherent in the Proposal.

\footnotetext{
107 Mr Manmohan Singh and Dermot Turing, Central Counterparties Resolution - an Unresolved Problem (International Monetary Fund, 2018).

108 Art. 40, 41 of the Proposal.

109 Art. 42, 43 of the Proposal.

110 Adam Ketessidis, "Resolving Systemically Important Financial Institutions and Markets," in The New International Financial System: Analyzing the Cumulative Impact of Regulatory Reform (World Scientific, 2016).

111 Art. 45(1)(c) of the Proposal.

112 Art. 45(1)(b) of the Proposal.
} 


\subsection{Externalities}

The sources of heretofore unaddressed externalities in CCP business mainly comes from the misaligned incentives originating from moral hazard problems resulting in externalities. Although a $\mathrm{CCP}$ is incentivized to avoid the risk of default by means of capital requirements - a mechanism that increases the CCP's skin in the game - and default funds, it is unlikely for the CCP to internalize the systemic risk that would arise from its operations. ${ }^{113}$ Under EMIR, margin requirements are mandatory for centrally cleared derivatives, however, the regulation does not require setting margins at any specific level and it is up to the CCP to set the margins. ${ }^{114}$ Because the CCP is a prudentially regulated financial institution, regulation expects that the CCP will set the margins at the optimal level. However, the CCP would not internalize the potential systemic risks of its operations. This is particularly true for the for-profit CCPs that are found to be undercapitalized and set lower collateral/margin requirements. ${ }^{115}$ This means that this type of CCPs is more likely to privatize profits and socialize losses.

Furthermore, given that CCPs are highly likely to be considered too-big, too-interconnected or tooimportant-to-fail, their incentives would not be aligned with those of the society due to the moral hazard problem arising from being recognized as such. ${ }^{116}$ This is why strong and harmonized regulatory minimum margin standards have been proposed. ${ }^{117}$ In addition, systemic liquidity events necessitate extending central bank liquidity facilities to CCPs, and in many jurisdictions such a liquidity backstop has been made available to CCPs. In Europe, Article 85(1)(a) of EMIR opens up the possibility for CCPs to have access to central bank liquidity facilities by mandating the Commission to assess, in cooperation with the members of the European System of Central Banks (ESCB), the need for any measure to facilitate the CCPs' access to central bank liquidity facilities. In some jurisdictions, such as the U.S., only banks (depository institutions) used to have access to central bank liquidity facilities. ${ }^{118}$ Although the Dodd-Frank Act does not expressly allow access to the Federal Reserve (Fed) liquidity facilities to CCPs, currently in the U.S. (and likewise in the UK), such access is granted. ${ }^{119}$ In those jurisdictions, where CCPs do not have direct access to central bank liquidity, it is of great importance for the CCP to have a banking license.

However, the dilemma in providing access to central bank liquidity facilities for CCPs is that it can increase the risk of moral hazard, as it is the case with any type of safety net. For example, such access to liquidity can encourage the CCP to offer lower margin requirements for its clearing

\footnotetext{
113 Hossein Nabilou and Alessio Pacces, "The Law and Economics of Shadow Banking," in Research Handbook on Shadow Banking: Legal and Regulatory Aspects, ed. Iris H. Chiu and Iain G. MacNeil (Cheltenham, UK: Edward Elgar Publishing Inc., 2018).; See also: Wenqian Huang, "Central Counterparty Capitalization and Misaligned Incentives," BIS Working Papers No 767 (2019).

114 Art. 41 EMIR.

115 Huang, "Central Counterparty Capitalization and Misaligned Incentives."

116 Nabilou and Pacces, "The Law and Economics of Shadow Banking."

117 Duffie, "Replumbing Our Financial System: Uneven Progress," 254.

118 Ibid.

119 Marc Dobler et al., "The Lender of Last Resort Function after the Global Financial Crisis," IMF Working Paper WP/16/10 (2016): 13-14.
} 
members. This problem can be amplified in case of too-big or too-important-to-fail CCPs. To mitigate the risks of moral hazard, access to liquidity facilities can be made subject to the Bagehot/Thornton rule and it should not be provided in lighter terms than that which is provided to banks and where possible should be subject to conditionality and enhanced supervision. ${ }^{120}$

\subsection{Resolution governance and collective action problem}

In terms of governance of the CCP recovery and resolution, it is only natural that enforcement will face significant challenges when resolution colleges include at least 14 different authorities reflecting in certain cases different national interests. On the one hand, pluralism is important when drafting resolution plans; but then, why not include more stakeholders, such as the competent authorities of the largest clearing members of the CCP, even if those users do not contribute - at least materially - to the default fund, but are systemically important to one Member State. ${ }^{121}$ The cross-border dimension of decisions is crucial since it affects not only the interests of banks, shareholders, and creditors in other countries, but also the interests of foreign taxpayers; home authorities are likely to try to save the CCP, whilst host authorities would likely focus on the protection of their local clearing members. For this reason, according to the Proposal, resolution plans need to be jointly agreed by all college members and they need to clearly specify the impact that their implementation shall have on clearing members and their clients, on the financial markets served by the $\mathrm{CCP}$, on any linked financial institutions, and on the financial system as a whole.

That said, the plurality of participants in resolution colleges could cause indecision or significant delays in decision-making. The economic literature suggests that in a repeated, cooperative public goods game with a small number of players and the presence of an effective threat of punishment, cooperation for the provision of public goods (e.g., provision of effective mechanisms for recovery and resolution) is likely to emerge. ${ }^{122}$ However, as the number of players increases, it is more likely that the cooperation would fail, because "as the number of participants becomes critically large, the individual will more and more come to treat the behavior of "all others" as beyond his own possible range of influence."123

This plurality of voices reflects both on resolution planning and resolution execution. First, in resolution planning it is important that all potential impediments to resolvability have been removed and all possible measures during the assessment phase have been taken; i.e. structural and

120 Walter Bagehot, Lombard Street: A Description of the Money Market (London: H.S. King, 1873).; Ross Cranston et al., Principles of Banking Law, 3 ed. (Oxford: Oxford University Press, 2017), 141.; See also: Dobler et al., "The Lender of Last Resort Function after the Global Financial Crisis," 15.; Freixas et al., "Lender of Last Resort: What Have We Learned since Bagehot?.";

121 Priem, "Ccp Recovery and Resolution: Preventing a Financial Catastrophe.", 10.

122 Ernst Fehr and Simon Gächter, "Cooperation and Punishment in Public Goods Experiments," The American Economic Review 90, no. 4 (2000).

123 James M. Buchanan, "Cooperation and Conflict in Public-Goods Interaction," Economic Inquiry 5, no. 2 (1967): $116 .$. According to Aristotle, "what is held in common by the largest number of people receives the least care." See Aristotle, Politics (Indianapolis: Hackett Publishing Company, 1998), 28.. This shows the commons or public goods feature of market discipline in this setting. 
organizational measures. That should improve the chances for a successful resolution and reduce the risks arising from moral hazard. Nevertheless, given the pluralism of different interests within the resolution colleges, it is highly unlikely that any such measures will be suggested. Second, when it comes to implementing the resolution plan, the resolution authority is not bound by it, and can deviate as long as it informs the resolution college and justifies the reasons underlying this deviation. This undermines the credibility of the execution process of a CCP resolution plan. Lessons from the BRRD suggest that the success of those provisions depends on the predictability of the economic outcome of the aforementioned actions for the CCP, their clearing members, other stakeholders and ultimately for any direct or indirect costs that may arise for the taxpayer. ${ }^{124}$ Only if all authorities' national interests are served to a sufficient extent, will they refrain from isolationist approaches.

In that respect, looking into the BRRD 'better brother', the SRMR, it would be useful to draw comparative conclusions. Under the SRMR, the SRB is competent to define in its executive session thus, without the National Resolution Authorities' (NRAs') approval - the resolution policies to be applied in all Member States. This effectively means that the entire resolution planning and execution is designed by the SRB, thus striping the NRAs of their powers and turning them into mere agents. Moreover, the SRB is the authority to conduct the resolvability assessment, which can ultimately lead to instructing the NRAs to take very intrusive measures against the institution concerned. ${ }^{125}$ Therefore, even though legitimacy and accountability concerns have been raised due to the extensive powers of the SRB as an EU agency, ${ }^{126}$ the GFC has proved that mechanisms built on consultations and cooperation among different national authorities are ineffective in times of crises, because the home authority is expected to be primarily concerned about the impact of the resolution on its own jurisdiction and to apply more isolationist approach. The SRB has thus come to the forefront as a necessity, ${ }^{127}$ and should be considered as part of the Proposal as well.

\subsection{Practical impediments}

Regarding the distinction between recovery and resolution, there are four main reasons why recovery measures are unlikely to be used. First, even though CCPs are heavily regulated and supervised, it would still be likely that the supervisory authorities might not acknowledge in a timely manner the fact that recovery proceedings may need to be initiated. ${ }^{128}$ The latter is also consistent with the supervisors' likely initial forbearance when a national financial institution is under financial

\footnotetext{
124 Jens-Hinrich Binder, "Cross-Border Coordination of Bank Resolution in the Eu: All Problems Resolved?," European Company and Financial Law Review 13, no. 4 (2016).

${ }^{125}$ Article 10(11) SRMR

${ }^{126}$ Council Legal Service, Opinion 14547/13 (7 October 2013); Merijn Chamon, "The Empowerment of Agencies under the Meroni Doctrine and Article 114 Tfeu: Comment on United Kingdom V. Parliament and Council (Short-Selling) and the Proposed Single Resolution Mechanism," European Law Review, no. 3 (2014).

127 Christos Lamaris-Adamis and Ioannis G. Asimakopoulos, "Into the Maze of Legitimacy and Efficiency; the Single Resolution Board as a Necessity," in (Re)Forming Public Administration: Paradigms in Global Governance Context, ed. Tatiana Dogaru (Editura Economica, 2018).

128 Vincent Bignon and Guillaume Vuillemey, "The Failure of a Clearinghouse: Empirical Evidence," (2017).
} 
distress. ${ }^{129}$ Consequently, resolution will most likely be required by the time the competent authority reacts.

Second, even though resolution authorities can exceptionally be the same entities as the supervisory ones ${ }^{130}$ this legal exception has become the standard practice in bank resolution. ${ }^{131}$ Notwithstanding the functional and organizational separation measures that can be put in place, ${ }^{132}$ it is likely that the national resolution authority would genuinely avoid questioning the work of the supervisory authority or favouring short-term fiscally beneficial solutions which can lead to significant delays in taking resolution action. Such architectural deficiencies may render early intervention inapplicable as well, given the inertia of the national supervisory and resolution authorities.

Third, as in the case of BRRD, the distinction between recovery and resolution is often blurred. In other words, resolution objectives are clear because resolution is the endgame of an entity's operations, whereas in recovery that is not the case. Recovery bears resemblance to a 'know-thyself' process rather than a credible mechanism that can improve the entity's chances of viability. Given the different structural and organizational attributes of a CCP compared to a credit institution, and the larger amount of the liquidity risk borne by CCPs - especially after standardized OTC derivatives' clearing became mandatory - it is important that CCPs and their supervisory and resolution authorities identify the flaws in CCPs' risk model in order to avoid failure.

Fourth, much more than in bank resolution, CCP resolution seems to be a one-way road in that liquidation is an unlikely option, because in the extreme scenario of failure what matters is that all accounts can be ported to another CCP and trading (and clearing) can continue. In particular, CCPs' critical functions are closely linked to the clearing of derivative contracts and liquidating a CCP would automatically lead to a disruption of these clearing functions. Thus, it seems difficult to understand at the moment how an authority could rule against the existence of public interest that would justify resolution. Having said so, there are no provisions in the Proposal that can effectively deal with the mitigation of such financial risks linked to the closure of a CCP, ${ }^{133}$ and given the fact that normal insolvency proceedings vary significantly from jurisdiction to jurisdiction, perhaps the Commission should also include common liquidation rules for CCPs. ${ }^{134}$ Such rules would also reduce the moral hazard risks that are significant given the current architecture of the Proposal.

\footnotetext{
129 Richard J. Herring, "Conflicts between Home and Host Country Prudential Supervisors," in International Financial Instability, ed. Douglas D. Evanoff, George G. Kaufman, and John R. LaBrosse (London: World Scientific Publishing Co. Pte. Ltd., 2007).

${ }^{130}$ Art. 3(3) of the Proposal.

${ }^{131}$ Pamela; Lintner et al., "Understanding Bank Recovery and Resolution in the Eu : A Guidebook to the Brrd (English) ", ed. D.C. : World Bank Group Washington (2016), $45 .$.

132 Ibid., 46.

133 Singh and Turing, Central Counterparties Resolution — an Unresolved Problem.. The authors point out the lack of any provision that would contribute to the mitigation of risks linked to the closure of a CCP.

${ }_{134}$ The only related element included in the Proposal at the moment is the possibility to suspend mandatory clearing of
} derivatives if the conditions for resolution are met. See Art. 80 of the Proposal. 


\section{Structural reforms as additional venues for strengthening CCP resilience}

The discussion of the ex-ante and ex-post regulation and resolution mechanisms and their shortcomings suggest that there is still room for improvements in terms of reforming the regulation and resolution mechanisms of CCPs. Thus far, we have highlighted the limitations of the current CCP regulatory regimes and have made suggestions to address such shortcomings, we now turn to discussing the potential reforms that can make CCPs more resilient in the face of financial distress by focusing on the potential improvements to the organizational and market structure of CCPs, as well as improvements to the proposal on the recovery and resolution. Therefore, in addition to addressing the shortcomings of the ex-ante and ex-post measures, certain structural measures would be considered.

The bank-CCP nexus, in particular in OTC derivatives clearing, originate from the existence of large exposures and interlinkages between small number of systemically important banks and even smaller number of systemically important CCPs. ${ }^{135}$ In this context, the clearing members and their affiliates are also significant providers of other critical services (such as credit, liquidity and settlement services) to CCPs and can have various relationships with several CCPs, resulting in a setting in which a small number of entities dominate each clearing network. ${ }^{136}$ Given these interconnectedness and the potential existing contagion channels between CCP clearing and other lines of businesses of a clearing entity, there seems to be a room for certain structural regulation in CCP clearing activities.

In banking regulation, structural measures have a relatively long history, which goes back to the Glass-Steagall Act. ${ }^{137}$ More recent permutations of such measures focus on prohibiting bank proprietary trading and banking entities' investment in and sponsorship of private funds, or ringfencing and subsidiarization as adopted in certain European jurisdictions. ${ }^{138}$ In the EU, this discussion was formalized with the Liikanen report ${ }^{139}$ and the subsequent Commission's proposal on a regulation on banking structural reforms. ${ }^{140}$ However, the proposal was finally withdrawn at the end of 2017 on the grounds that it was impossible to accurately estimate the costs and benefits and the trade-off between market efficiency and financial stability.

135 BCBS et al., "Analysis of Central Clearing Interdependencies."; BCBS et al., "Analysis of Central Clearing Interdependencies."; See also: Faruqui, Huang, and Takáts, "Clearing Risks in Otc Derivatives Markets: The Ccp-Bank Nexus," 73.

${ }^{136}$ BCBS et al., "Analysis of Central Clearing Interdependencies," 3.

137 Georg J. Benston, The Separation of Commercial and Investment Banking: The Glass-Steagall Act Revisited and Reconsidered (London: Oxford University Press, 1990).; Hossein Nabilou, "A Tale of Regulatory Divergence: Contrasting Transatlantic Policy Responses to the Alleged Role of Alternative Investment Funds in Financial Instability," Capital Markets Law Journal 12, no. 1 (2017). https://doi.org/10.1093/cmlj/kmw031.

${ }^{138}$ For an overview see: Hossein Nabilou, "Bank Proprietary Trading and Investment in Private Funds: Is the Volcker Rule a Panacea or yet Another Maginot Line?," Banking and Finance Law Review 32, no. 2 (2017).; Matthias Lehmann, "Volcker Rule, Ring-Fencing or Separation of Bank Activities - Comparison of Structural Reform Acts around the World," Journal of Banking Regulation 17, no. 3 (2016). https://doi.org/10.1057/jbr.2015.3.; José Viñals et al., Creating a Safer Financial System: Will the Volcker, Vickers, and Liikanen Structural Measures Help?, Imf Staff Discussion Note (International Monetary Fund, 2013).

139 Erkki Liikanen, "High-Level Expert Group on Reforming the Structure of the Eu Banking Sector: Final Report," (Brussels2012).

140 Proposal for a Regulation of the European Parliament and of the Council on Structural Measures Improving the Resilience of the EU Credit Institutions, Brussels, 29.1.2014, COM(2014) 43 final, 2014/0020 (COD). This proposal is available at: http://eur-lex.europa.eu/legal-content/EN/TXT/PDF/?uri=CELEX:52014PC0043\&from=EN 
Although the doors for imposing structural measures at the EU levels appease to be closed for the foreseeable future, such measures have found a backdoor to enter. Currently these measures can be imposed in the bank recovery and resolution framework, and the same would apply to CCPs under the Proposal. In particular, under the BRRD, the SRMR, and the Proposal, resolution authorities can - as part of resolution planning - order any institution to apply measures that can be of structural or financial nature, or can involve additional information disclosure requirements, on which the authorities have a wide discretion. ${ }^{141}$

But unlike banking, structural regulation would take different forms in CCPs. This is because in addition to the nature of activities, the organizational structure of CCPs are also different from banks. FMIs have historically taken a variety of legal and organizational forms, functions and designs. They may be organized as associations of financial institutions, non-bank clearing corporations and specialized banking organizations. FMIs have also varying ownership structures. They may be owned and operated by central banks or by the private sector. They may be organized as for-profit or not-forprofit entities. ${ }^{142}$ By the same token, CCPs have taken many legal forms. A CCP can be organized as a bank, or as a special purpose financial utility (SPV or SPE), or it can be owned and operated by an exchange in a vertically integrated structure.

Due to various external drivers, in terms of the organizational and market structure, the CCP business model has taken four main structures: vertical integration along the value chains, horizontal integration, competition among CCPs, and vertical specialization with the emergence of niche service providers. ${ }^{143}$ However, two dominant models of CCPs resulting from a century-old history are vertically structured CCPs and horizontally structured CCPs. Vertically-structured CCPs are integrated within a corporate entity or group which provides a variety of services from trading to settlement. The vertical integration is the dominant pattern for futures exchanges around the globe. ${ }^{144}$ Despite the various organizational and market structures, theoretical studies and empirical evidence show that no single CCP structure or even market structure in the CCP business is superior to another. ${ }^{145}$

In addition to the organic developments in the organization and structure of CCPs, the law can also play a key role in shaping the structure of CCPs by deploying ex-ante structural regulation with the

\footnotetext{
${ }^{141}$ It is worth noting that even during the time when the BRRD/SRMR proposal was being negotiated, the overlap of the Commission's proposed regulatory powers and the resolution authorities' preventive powers had been acknowledged. JensHinrich Binder, "Resolution Planning and Structural Bank Reform within the Banking Union," in European Banking Union (Routledge, 2015). However, as aforementioned, the enforceability of those measures is much stronger in the SRMR than in the BRRD and the Proposal, because the SRB can effectively bypass national authorities and instruct private entities directly.

${ }^{142}$ Committee on Payment and Settlement Systems and Technical Committee of the International Organization of Securities Commissions, "Principles for Financial Market Infrastructures," (Basel, Switzerland: Bank for International Settlements and International Organization of Securities Commissions, 2012), 7.

${ }^{143}$ Committee on Payment and Settlement Systems Bank for International Settlements, "Market Structure Developments in the Clearing Industry: Implications for Financial Stability: Report of the Working Group on Post-Trade Services," (Basel, Switzerland: Bank for International Settlements, 2010), 7-8.

${ }_{144}$ Norman, The Risk Controllers: Central Counterparty Clearing in Globalised Financial Markets, 17-18.

145 Bank for International Settlements, "Market Structure Developments in the Clearing Industry: Implications for Financial Stability: Report of the Working Group on Post-Trade Services."
} 
aim of mitigating systemic risks. Structural regulation has historically been one of the main regulatory measures in regulating financial markets. ${ }^{146}$ In contrast to other modalities of regulation, ${ }^{147}$ which rely on rational human reasoning, structural regulation ${ }^{148}$ seeks to "eliminate undesirable behaviour by designing out the possibility for its occurrence." This instrument seeks to remove the possibility of non-compliance by eliminating the possibility for the application of human discretion in its entirety. ${ }^{149}$ This approach has a variety of applications in the regulation of cyberspace. In this perspective, the code is viewed as the architectural alternative for the deployment of legal rules. ${ }^{150}$ In other words, structural regulation creates "a 'structure' that will organize, constrain and channel activity."151

The ethos of post-GFC regulatory reforms is that regulation should be designed in such a way as to allow financial institutions to fail with minimum disruption to financial markets. In other words, the financial regulation should ensure that the markets could easily tolerate the failure of large financial institutions. ${ }^{152}$ Such an approach constitutes the core of the BRRD, and the SRMR, and more importantly the Proposal. However, as it is explained, it might not be workable for the FMIs. ${ }^{153}$

The alternative approach is that the public policy objective should aim at making it extremely difficult for a CCP to fail, ${ }^{154}$ and the design and regulation of CCPs should be shaped as though they are tooimportant-to-fail, ${ }^{155}$ because the expected social costs of a failure of a CCP would far exceed the expected cost of a safer design, even taking into account the costs of moral hazard and eventual bailouts. In this view, ex-ante structural measures could be deployed to achieve such an objective. For example, structural measures can be used to address some of the problems stemming from the interconnectedness of banking entities with CCPs.

Structural measures in the CCP business model can take a variety of forms such as ring-fencing, requiring the $\mathrm{CCP}$ to be formed as a special purpose vehicle (SPV), imposing a mutually owned (user-

\footnotetext{
146 See: Nabilou, "Bank Proprietary Trading and Investment in Private Funds: Is the Volcker Rule a Panacea or yet Another Maginot Line?."

147 For a discussion of such modalities, see: Bronwen Morgan and Karen Yeung, An Introduction to Law and Regulation: Texts and Materials (New York: Cambridge University Press, 2007), 9 \& 80.

${ }^{148}$ Structural regulation is also called code-based or architecture-based regulation (sometimes called design-based regulation or techno-regulation).

${ }^{149}$ Morgan and Yeung, An Introduction to Law and Regulation: Texts and Materials, 102. Although it seems that the designbased regulation has the promise of one hundred percent effectiveness, they may fall short of such grand expectations. (Lawrence Lessig argues that "Law as code is a start to the perfect technology of justice. see Lawrence Lessig, "The Zones of Cyberspace," Stanford Law Review 48 (1996): 1408.), See also: Karen Yeung, "Towards an Understanding of Regulation by Design," in Regulating Technologies: Legal Futures, Regulatory Frames and Technological Fixes, ed. Roger Brownsword and Karen Yeung (Portland, Oregon: Hart Publishing, 2008), 80 \& 106.

${ }^{150}$ Lawrence Lessig, Code: And Other Laws of Cyberspace (New York: Basic Books, 1999).

Examples of design-based rules abound. Benthamite panopticon is one of the earliest examples of the use of design-based techniques in law enforcement. See Michel Foucault, Discipline and Punish: The Birth of the Prison (New Yrok: Vintage Books, 1995), 195-228. The ubiquitous use of speed humps is another example. The idea of separation of powers (See: John C. Coates IV, "The Volcker Rule as Structural Law: Implications for Cost-Benefit Analysis and Administrative Law," Capital Markets Law Journal 10, no. 4 (2015): 449.) and even locating constitutional courts away from the seat of the legislative and the executive branches of government in some European countries with the aim of ensuring judicial independence is one of the examples of design-based regulation. See Lawrence Lessig, Code: Version 2.0 (New York: Basic Books, 2006), 127-28.

151 Coates IV, "The Volcker Rule as Structural Law: Implications for Cost-Benefit Analysis and Administrative Law," 448.

152 Duffie, "Replumbing Our Financial System: Uneven Progress," 252-53.

153 Ibid.

154 Ibid.

155 Ibid., 253.
} 
owned) ownership structure or subsidiarisation requirement with the parent company having direct access to central bank liquidity facilities. ${ }^{156}$ In addition, restrictions on the affiliations with and investments in affiliates could be placed under structural measures. One major benefit of such structural measures and separation of banking and CCP business would be that such separation can function as a firewall and prevent the contagion of shocks from banks to CCPs and vice versa.

As discussed under the recovery and resolution measures, according to the Proposal, certain structural measures can also be deployed under such measures. Under these rules, the competent authorities have the power to request from financial institutions to execute, inter alia, any kind of structural measure to improve the resolvability of the latter. As regards recovery plans, supervisory and resolution authorities can direct an institution to make specific changes to the plan in order to correct for any 'material deficiencies' or 'material impediments' identified therein; ${ }^{157}$ structural reforms being within the possible measures that can be requested. As regards resolution plans, resolution authorities are exclusively competent to draft them for each financial institution that falls under their scope. Again, as part of resolution planning and in the case that 'material impediments to resolvability' are identified, structural measures can be requested. In both cases, structural measures can include any form of legal and organizational restructuring, establishing a parent holding company, divesting certain businesses, etc. ${ }^{158}$

Traditionally, there has been a very close relationship between CCP and banking business. This can partly be explained by the traditional bank-based European financial systems, ${ }^{159}$ European universal banking model, ${ }^{160}$ and the liquidity needs of the CCPs that necessitated access to central bank liquidity. However, a case can be made against comingling banking with CCPs as risks from banking activities might contaminate CCP functions. From this perspective, CCPs would better be organized as special purpose CCPs with direct access to central bank liquidity facilities.

From a structural point of view, the clearing function of a bank is a systemic function and similar to core banking functions, which are separated under the ring-fencing requirements, can be separated or subsidiarized. In other words, structural regulation can be deployed to give CCPs such design features that would make it near fail-proof. However, the downside is that such a regulatory objective would inevitably create moral hazard. For example, the moral hazard aspect could stem from the lender of last resort services provided by the central bank to the CCP. This moral hazard problem can be reduced by restricting the scope of risk-taking activities of the CCP, as well as conservative pricing of

\footnotetext{
156 Although there are market failure concerns about the CCPs in terms of competition and information asymmetry, this paper is only concerned with the systemic-risk aspects of the CCP business model.

${ }_{157}$ Article 6(4) and 6(5) BRRD.

158 EBA, Gudelines on the Specification of Measures to Reduce or Remove Impediments to Resolvability and the Circumstances in Which Each Measure May Be Applied under Directive 2014/59/Eu (19 December 2014).

${ }_{159}$ Ross Levine, "Bank-Based or Market-Based Financial Systems: Which Is Better?," Journal of Financial Intermediation 11, no. 4 (2002/10/01 2002). https://doi.org/http://dx.doi.org/10.1006/jfin.2002.0341.

${ }^{160}$ Charles Calomiris, "The Costs of Rejecting Universal Banking: American Finance in the German Mirror, 1870-1914," in Coordination and Information: Historical Perspectives on the Organization of Enterprise, ed. Naomi R. Lamoreaux and Daniel M. G. Raff (Chicago: University of Chicago Press, 1995).; Anthony Saunders and Ingo Walter, "Financial Architecture, Systemic Risk, and Universal Banking," Financial Markets and Portfolio Management 26, no. 1 (2012).
} 
central bank liquidity. ${ }^{161}$ In any case, the scope for moral hazard in financial market utilities would be relatively narrow, and the design and regulation of some of the financial market utilities as if they were too-important-to-fail would be socially optimal. This line of reasoning leads to an argument for not mixing the operations and capital structure of financial market utilities with more complex financial institutions if the regulatory objective is to let the financial institutions fail. ${ }^{162}$

\section{Conclusion}

This paper studied both ex-ante and ex-post regulation of CCPs in Europe with a focus on EMIR and the European proposal for the recovery and resolution of CCPs. The aim of the ex-ante regulatory measures is to prevent the CCP from failing. Such measures are mainly included in EMIR. We also studied the ex-post regulatory measures - whose aim is to mitigate systemic risks after the failure of a CCP - which are mainly included in the European proposal for recovery and resolution of CCPs.

Although, by way of backward induction, a credible resolution regime for CCPs can affect the sequence of optimal actions and decisions that the managers, shareholders and users of the CCP should take to avoid financial calamity, such a resolution regime - as is put forward in the Proposal falls short of providing a credible resolution scheme for CCPs. In addition to potential concerns about externalities and misaligned incentives within the ex-ante prudential regulation framework, we have uncovered potential shortcomings, especially in terms of coordination failures both within the resolution colleges and between the competent resolution authority and resolution colleges, that could jeopardize a credible CCP recovery and resolution regime. In other words, it is likely that the current proposed special resolution regime for CCPs would fall short of creating incentives for the CCP's users, owners, and managers to take socially optimal actions. These shortcomings in the Proposal would ultimately force the taxpayers to foot the bill.

Given the limitations of the existing regulatory and resolution framework for CCPs and since the major CCPs are highly likely to become too-important-to-fail, strengthening ex-ante regulatory measures should take precedence over ex-post measures, in particular in terms of separating the operations and capital structure of CCPs from more complex financial institutions. This becomes extremely important if the regulatory objective is to make it extremely unlikely for a CCP to fail due to their too-interconnected-to-fail status, and to let other financial institutions fail without recourse to the taxpayer money.

Future studies could investigate improving the Proposal by introducing mechanisms such as higher centralization of CCP resolution authorities - following the SRB model of SRMR - to mitigate potential coordination and holdout problems. In addition, addressing the specific shortcomings of the ex-ante regulation of CCPs can be an important research area within which structural regulation could be considered as a viable option. In this regard, future research could focus on investigating whether

${ }^{161}$ Duffie, "Replumbing Our Financial System: Uneven Progress," 253-54.

162 Ibid., 252-53. 
the structural separation of CCPs from other banking and financial institutions - modelled after utility companies - would fare better than the existing CCP structures. In case a complete separation would be infeasible for the CCPs integrated in a banking group, subsidiarization or ring-fencing measures could be examined to explore the potential for isolating the risks of activities in different sections of the firm from the risks originating from clearing functions. 


\section{Bibliography}

Admati, Anat R., and Martin Hellwig. The Bankers' New Clothes: What's Wrong with Banking and What to Do About It. Princeton, New Jersey: Princeton University Press, 2013.

Adrian, Tobias, and Adam B. Ashcraft. "Shadow Banking Regulation." Federal Reserve Bank of New York Staff Report, no. 559 (2012).

Aristotle. Politics. Indianapolis: Hackett Publishing Company, 1998.

Bagehot, Walter. Lombard Street: A Description of the Money Market. London: H.S. King, 1873.

Bank, European Central. Financial Stability Review. May 2016.

Bank for International Settlements, Committee on Payment and Settlement Systems. "Market Structure Developments in the Clearing Industry: Implications for Financial Stability: Report of the Working Group on Post-Trade Services." Basel, Switzerland: Bank for International Settlements, 2010.

Basel Committee on Banking Supervision. "Capital Requirements for Bank Exposures to Central Counterparties." Basel: Bank for International Settlements, April 2014.

BCBS, CPMI, FSB, and OICU-IOSCO. "Analysis of Central Clearing Interdependencies." (9 August 2018).

"Analysis of Central Clearing Interdependencies." (5 July 2017).

Benston, Georg J. The Separation of Commercial and Investment Banking: The Glass-Steagall Act Revisited and Reconsidered. London: Oxford University Press, 1990.

Bignon, Vincent, and Guillaume Vuillemey.. "The Failure of a Clearinghouse: Empirical Evidence." Banque de France Working Paper No. 638 (2017).

Binder, Jens-Hinrich. "Cross-Border Coordination of Bank Resolution in the Eu: All Problems Resolved?". European Company and Financial Law Review 13, no. 4 (2016): 575-98. . "Resolution Planning and Structural Bank Reform within the Banking Union." In European Banking Union, 147-73: Routledge, 2015.

Blinder, Alan S., and Robert F. Wescott. "Reform of Deposit Insurance: A Report to the Fdic." 2001.

Braithwaite, Jo. "The Dilemma of Client Clearing in the Otc Derivatives Markets." European Business Organization Law Review 17, no. 3 (2016): 355-78. https://doi.org/10.1007/s40804016-0044-0.

Braithwaite, Jo, and David Murphy. "Central Counterparties (Ccps) and the Law of Default Management." Journal of Corporate Law Studies (2017): 1-35. https://doi.org/10.1080/14735970.2016.1254448. . "Got to Be Certain: The Legal Framework for Ccp Default Management Processes." Bank of England Financial Stability Paper No. 37 (2016).

Bruner, Robert F., and Sean D. Carr. The Panic of 1907: Lessons Learned from the Market's Perfect Storm. Hoboken, New Jersey: John Wiley \& Sons, Inc., 2007.

Buchanan, James M. "Cooperation and Conflict in Public-Goods Interaction." Economic Inquiry 5, no. 2 (1967): 109-21.

Calomiris, Charles. "The Costs of Rejecting Universal Banking: American Finance in the German Mirror, 1870-1914." Chap. 8 In Coordination and Information: Historical Perspectives on the Organization of Enterprise, edited by Naomi R. Lamoreaux and Daniel M. G. Raff, 257-321. Chicago: University of Chicago Press, 1995.

Calomiris, Charles W. "Is Deposit Insurance Necessary? A Historical Perspective." The Journal of Economic History 50, no. 02 (1990): 283-95.

Chamon, Merijn. "The Empowerment of Agencies under the Meroni Doctrine and Article 114 Tfeu: Comment on United Kingdom V. Parliament and Council (Short-Selling) and the Proposed Single Resolution Mechanism." European Law Review, no. 3 (2014): 380 - 403.

Coates IV, John C. "The Volcker Rule as Structural Law: Implications for Cost-Benefit Analysis and Administrative Law." Capital Markets Law Journal 10, no. 4 (2015): 447-68.

Committee on Payment and Settlement Systems, and Technical Committee of the International Organization of Securities Commissions. "Principles for Financial Market Infrastructures." Basel, Switzerland: Bank for International Settlements and International Organization of Securities Commissions, 2012.

. "Recommendations for Central Counterparties: Consultative Report." (March 2004).

Committee on Payments and Market Infrastructures, and Technical Committee of the International Organization of Securities Board of the International Organization of Securities 
Commissions. "Recovery of Financial Market Infrastructure." Basel, Switzerland: Bank for International Settlements and International Organization of Securities Commissions, 2017.

Cont, Rama. "The End of the Waterfall: Default Resources of Central Counterparties." Journal of Risk Management in Financial Institutions 8, no. 4 (2015): 365-89.

Corrigan, E. Gerald. "Are Banks Special?": Federal Reserve Bank of Minneapolis, 1982.

2000.

Council Legal Service. Opinion 14547/13, 7 October 2013.

Cox, Robert T., David Murphy, and Edward Budding. "Central Counterparties in Crisis: International Commodities Clearing House, New Zealand Futures and Options Exchange and the Stephen Francis Affair." Journal of Financial Market Infrastructures 4, no. 3 (2016): 65-92. https://doi.org/10.21314/JFMI.2016.054.

Cox, Robert T., and Robert S Steigerwald. "A Ccp Is a Ccp Is a Ccp." Federal Reserve Bank of Chicago WP2004-2 PDP, no. 2017-1 (April 2017).

Cranston, Ross, Emilios Avgouleas, Kristin van Zwieten, Christopher Hare, and Theodor van Sante. Principles of Banking Law. 3 ed. Oxford: Oxford University Press, 2017.

de Groen, Willem Pieter. "The Provision of Critical Functions at Global, National or Regional Level. Is There a Need for Further Legal/Regulatory Clarification If Liquidation Is the Default Option for Failing Banks? Ceps Special Report, 19 December 2017." (2017).

Dirk, Heremans. "Regulation of Banking and Financial Markets." In Encyclopedia of Law and Economics Volume 9, edited by Roger J. Van den Bergh and Alessio M. Pacces, 950-86. Cheltenham: Edward Elgar Publishing, 2011.

Dobler, Marc, Simon Gray, Diarmuid Murphy, and Bozena Radzewicz-Bak. "The Lender of Last Resort Function after the Global Financial Crisis." IMF Working Paper WP/16/10 (2016).

Duffie, Darrell. "Replumbing Our Financial System: Uneven Progress." International Journal of Central Banking 9, no. 1 (2013): 251-79.

Duffie, Darrell, and Haoxiang Zhu. "Does a Central Clearing Counterparty Reduce Counterparty Risk?". The Review of Asset Pricing Studies 1, no. 1 (2011): 74-95. https://doi.org/10.1093/rapstu/rar001.

EBA. Gudelines on the Specification of Measures to Reduce or Remove Impediments to Resolvability and the Circumstances in Which Each Measure May Be Applied under Directive 2014/59/Eu, 19 December 2014.

Elliott, David. "Central Counterparty Loss-Allocation Rules." Bank of England Financial Stability Paper No. 2020 (April 2013).

European Commission. "Impact Assessment Proposal for a Regulation of the European Parliament and of the Council on a Framework for the Recovery and Resolution of Central Counterparties and Amending Regulations (Eu) No 1095/2010, (Eu) No 648/2012, and (Eu) 2015/2365 \{Swd(2016) 369 Final\}." (28.11.2016).

Fama, Eugene F. "Banking in the Theory of Finance." Journal of monetary economics 6, no. 1 (1980): $39-57$. "What's Different About Banks?". Journal of monetary economics 15, no. 1 (1985): 29-39.

Faruqui, Umar, Wenqian Huang, and Elöd Takáts. "Clearing Risks in Otc Derivatives Markets: The Ccp-Bank Nexus." BIS Quarterly Review December 2018 (2018).

Federal Reserve Bank of New York. "Tri-Party Repo Infrastructure Reform." 2018.

Fehr, Ernst, and Simon Gächter. "Cooperation and Punishment in Public Goods Experiments." The American Economic Review 90, no. 4 (2000): 980-94.

Financial Services Authority. The Turner Review: A Regulatory Response to the Global Banking Crisis. 2009.

Financial Stability Board. "Implementing Otc Derivatives Market Reforms." 2010.

Foucault, Michel. Discipline and Punish: The Birth of the Prison. New Yrok: Vintage Books, 1995.

Freixas, Xavier, Curzio Giannini, Glenn Hoggarth, and Farouk Soussa. "Lender of Last Resort: What Have We Learned since Bagehot?". Journal of Financial Services Research 18, no. 1 (2000): 63-84.

Freixas, Xavier, and Bruno M. Parigi. "The Lender of Last Resort of the 21st Century." In The First Global Financial Crisis of the 21st Century: Part Ll June-December 2008, edited by Andrew Felton and Carmen M. Reinhart, 163-67: VoxEU.org Publication, 2009.

Garcia-de-Andoain, Carlos, Florian Heider, Marie Hoerova, and Simone Manganelli. "Lending-ofLast-Resort Is as Lending-of-Last-Resort Does: Central Bank Liquidity Provision and 
Interbank Market Functioning in the Euro Area." ECB Working Paper Series No 1886 (2016).

Gorton, Gary B. Misunderstanding Financial Crises: Why We Don't See Them Coming. New York: Oxford University Press, 2012.

. Slapped by the Invisible Hand: The Panic of 2007. New York: Oxford University Press, 2010.

Greenbaum, Stuart I., Anjan V. Thakor, and Arnoud W. A. Boot. "Objectives of Bank Regulation." Chap. 15 In Contemporary Financial Intermediation, edited by Stuart I. Greenbaum, Anjan V. Thakor and Arnoud W. A. Boot, 355-95. San Diego: Academic Press, 2016.

Herring, Richard J. "Conflicts between Home and Host Country Prudential Supervisors." In International Financial Instability, edited by Douglas D. Evanoff, George G. Kaufman and John R. LaBrosse, 201-19. London: World Scientific Publishing Co. Pte. Ltd., 2007.

Herring, Richard J., and Anthony M. Santomero. "What Is Optimal Financial Regulation?". In The New Financial Architecture: Banking Regulation in the Twenty-First Century., edited by Benton E. Gup, 51-84. Westport, Connecticut: Quorum Books, 2000.

Hills, Bob, David Rule, Sarah Parkinson, and Chris Young. "Central Counterparty Clearing Houses and Financial Stability." Financial Stability Review, Bank of England 6, no. 2 (1999): 122-34.

Huang, Wenqian. "Central Counterparty Capitalization and Misaligned Incentives." BIS Working Papers No 767 (2019).

Huertas, Thomas. "How to Deal with the Resolution of Financial Market Infrastructures." (2016).

Hughes, David, and Mark Manning. "Ccps and Banks: Different Risks, Different Regulations." Reserve Bank of Australia Bulletin (December 2015): 67-80.

International Capital Market Association. "Frequently Asked Questions on Repo." edited by International Capital Market Association (ICMA), 2015.

Ketessidis, Adam. "Resolving Systemically Important Financial Institutions and Markets." In The New International Financial System: Analyzing the Cumulative Impact of Regulatory Reform, 307-14: World Scientific, 2016.

Kindleberger, Charles P., and Robert Z. Aliber. Manias, Panics, and Crashes: A History of Financial Crises. Vol. 5, Hoboken, New Jersey: John Wiley \& Sons, Inc., 2005.

Lamaris-Adamis, Christos, and Ioannis G. Asimakopoulos. "Into the Maze of Legitimacy and Efficiency; the Single Resolution Board as a Necessity." In (Re)Forming Public Administration: Paradigms in Global Governance Context, edited by Tatiana Dogaru: Editura Economica, 2018.

Lehmann, Matthias. "Volcker Rule, Ring-Fencing or Separation of Bank Activities - Comparison of Structural Reform Acts around the World." Journal of Banking Regulation 17, no. 3 (2016): 176-87. https://doi.org/10.1057/jbr.2015.3.

Lessig, Lawrence. Code: And Other Laws of Cyberspace. New York: Basic Books, 1999.

. Code: Version 2.0. New York: Basic Books, 2006. . "The Zones of Cyberspace." Stanford Law Review 48 (1996): 1403-11.

Levine, Ross. "Bank-Based or Market-Based Financial Systems: Which Is Better?". Journal of Financial Intermediation 11, no. 4 (2002/10/01 2002): 398-428. https://doi.org/http://dx.doi.org/10.1006/jfin.2002.0341.

Liikanen, Erkki. "High-Level Expert Group on Reforming the Structure of the Eu Banking Sector: Final Report." Brussels, 2012.

Lintner, Pamela; , Marie Anne Johanna; Lincoln Nagy, Piotr; Pyziak, Andrew John; Godwin, Susan Caroline; Schroeder, and Nurgul Irsalieva. "Understanding Bank Recovery and Resolution in the Eu : A Guidebook to the Brrd (English) ", edited by D.C. : World Bank Group Washington, 2016.

Loader, David. Clearing, Settlement and Custody. Second ed. Oxford: Elsevier ButterworthHeinemann, 2014.

Manning, Mark Jozsef, and David Hughes. "Central Counterparties and Banks: Vive La Difference." Journal of Financial Market Infrastructures 4, no. 3 (2016): 1-24.

Marcus, Alan J. "Deregulation and Bank Financial Policy." Journal of Banking \& Finance 8, no. 4 (1984): 557-65. https://doi.org/10.1016/S0378-4266(84)80046-1.

Merler, Silvia. "Critical Functions and Public Interest in Banking Services: Need for Clarification? Banking Union Scrutiny. Bruegel Report, November 2017." (2017). 
Moloney, Niamh. Eu Securities and Financial Markets Regulation. 3 ed. Oxford: Oxford University Press, 2014.

Morgan, Bronwen, and Karen Yeung. An Introduction to Law and Regulation: Texts and Materials. New York: Cambridge University Press, 2007.

Nabilou, Hossein. "Bank Proprietary Trading and Investment in Private Funds: Is the Volcker Rule a Panacea or yet Another Maginot Line?". Banking and Finance Law Review 32, no. 2 (2017): 297-341.

"A Tale of Regulatory Divergence: Contrasting Transatlantic Policy Responses to the Alleged Role of Alternative Investment Funds in Financial Instability." Capital Markets Law Journal 12, no. 1 (2017): 94-122. https://doi.org/10.1093/cmlj/kmw031.

Nabilou, Hossein, and Alessio Pacces. "The Law and Economics of Shadow Banking." Chap. 1 In Research Handbook on Shadow Banking: Legal and Regulatory Aspects, edited by Iris H. Chiu and Iain G. MacNeil, 7-46. Cheltenham, UK: Edward Elgar Publishing Inc., 2018.

Norman, Peter. The Risk Controllers: Central Counterparty Clearing in Globalised Financial Markets. Chichester, West Sussex: John Wiley \& Sons, Ltd., 2011.

Priem, Randy. "Ccp Recovery and Resolution: Preventing a Financial Catastrophe." (2017).

Saunders, Anthony, and Ingo Walter. "Financial Architecture, Systemic Risk, and Universal Banking." Financial Markets and Portfolio Management 26, no. 1 (2012): 39-59.

Singh, Manmohan, and Dermot Turing. "Central Counterparty Resolution: An Unresolved Problem." IMF Working Paper WP/18/65 (2018).

Singh, Mr Manmohan, and Dermot Turing. Central Counterparties Resolution-an Unresolved Problem. International Monetary Fund, 2018.

Viñals, José, Ceyla Pazarbasioglu, Jay Surti, Aditya Narain, Mrs Michaela Erbenova, and Mr Julian TS Chow. Creating a Safer Financial System: Will the Volcker, Vickers, and Liikanen Structural Measures Help? Imf Staff Discussion Note. International Monetary Fund, 2013.

Wu, Songjiwen, and Hossein Nabilou. "Repo Markets across the Atlantic: Similar but Unalike." European Business Law Review (forthcoming) (2018).

Yeung, Karen. "Towards an Understanding of Regulation by Design." In Regulating Technologies: Legal Futures, Regulatory Frames and Technological Fixes, edited by Roger Brownsword and Karen Yeung, 79-107. Portland, Oregon: Hart Publishing, 2008. 